\title{
Excitotoxic Cell Death and Delayed Rescue in Human Neurons Derived from NT2 Cells
}

\author{
Muhammad Munir, Lisha Lu, and Paul McGonigle \\ Department of Pharmacology, University of Pennsylvania School of Medicine Philadelphia, Pennsylvania 19104
}

The excitotoxic response of NT2-N cells, a clonal line of human teratocarcinoma cells that are terminally differentiated into neuron-like cells, was examined using several endpoints. A $15 \mathrm{~min}$ exposure to glutamate produced a dose-dependent toxicity with a maximal cell loss of $80-90 \%$ in 6 week old cells. The rapidly triggered excitotoxicity induced by glutamate was blocked by NMDA selective antagonists, was calcium dependent and $\mathrm{pH}$ sensitive and could be mimicked by NMDA but not by non-NMDA agonists, AMPA, kainate or quisqualate. The non-NMDA agonists however caused toxicity on prolonged exposure. The NMDA receptor modulators glycine and spermidine enhanced glutamate-mediated toxicity whereas ifenprodil potently and completely inhibited toxicity suggesting that the toxic response is mediated by the NR1/NR2 combination of NMDA subunits. These cells can be rescued from death up to $1 \mathrm{hr}$ after removal of glutamate by NMDA receptor blockade, removal of extracellular $\mathrm{Ca}^{2+}$ or lowering of $\mathrm{pH}$. The extent of rescue is directly related to the time elapsed before intervention. Blockade of NMDA receptor activity for $1 \mathrm{hr}$ immediately after removal of glutamate is both necessary and sufficient for complete rescue. Glutamate-mediated toxicity was not prevented by nitric oxide synthase inhibitors nor was nitric oxide synthase detected in NT2-N cells indicating that nitric oxide is not required for glutamate-mediated excitotoxicity. In summary, NT2-N cells exhibit a robust excitotoxic response and represent a novel model system in which to study the molecular basis of excitotoxic cell death.

[Key words: calcium, excitotoxicity, glutamate, ifenprodil, inhibitors, mechanisms, nitric oxide, NMDA, nonNMDA, nitric oxide synthase (NOS), NR1/NR2 ${ }_{B}, p H$, rescue, spermidine, spermine, teratocarcinoma]

There is mounting evidence that excitotoxicity contributes to the neuronal loss associated with several neurological disorders including stroke, trauma, hypoglycemia, and epilepsy as well as neurodegenerative diseases such as Huntington's and Alzhei mer's disease (Meldrum, 1985; Rothman and Olney, 1987; Choi, 1988). The clinical significance of excitotoxicity has stimulated an intense effort to elucidate the molecular mechanisms under-

Received July 7, 1995; revised Aug. 28, 1995; accepted Aug. 31, 1995.

We thank Drs. Virginia Lee, Michael Robinson, Keith Williams, and David Weiner for their support of the project. This work was supported by Grants GM-34781 and NS-08803 from the USPHS.

Correspondence should be addressed to Paul McGonigle, Department of Pharmacology, 159 Johnson Pavilion, University of Pennsylvania School of Medicine, Philadelphia, PA 19104.

Copyright (C) 1995 Society for Neuroscience $0270-6474 / 95 / 157847-14 \$ 05.00 / 0$ lying this phenomenon. In vivo studies of these mechanisms have been hampered by the complexity of the CNS and the existence of robust glutamate uptake systems. Consequently, our current understanding of excitotoxicity has been obtained primarily from studies using dissociated primary neuronal cultures (Choi, 1985; Rothman ct al., 1987; Choi ct al., 1988). On the basis of these studies, excitotoxicity has been proposed to consist of at least three distinct stages: induction, amplification, and expression (Choi, 1992). Excitotoxicity is induced by excessive stimulation of glutamate receptors producing an influx of $\mathrm{Ca}^{2+}$ that triggers a cascade of intracellular events. This intracellular cascade includes an amplification component that when interrupted, results in delayed rescue. Barring prompt pharmacological intervention, the intracellular cascade ultimately results in the expression of toxicity, that is, intracellular derangement followed by cell death (Choi, 1992).

There are certain limitations associated with the use of rodent primary cultured neurons to explore human excitotoxicity. The genctic composition of these postmitotic neurons cannot be manipulated, there are a variety of cell types present and they are not human cells. Clonal neuroblastoma cell lines, such as N18 RE-105 and N18TG-2, are sensitive to glutamate but their toxic response is fundamentally different from that observed in primary cultured neurons (Murphy et al., 1989; Chovanes et al., 1992). The HCN lines of human cerebral cortical cells exhibit neuronal properties after differentiation but have not been shown to express glutamate receptors (Ronnett et al., 1990; Ronnett et al., 1994). Recently, promising results have been obtained with P19 cells, a mouse embryonal carcinoma line that can be differentiated into neuron-like cells (Ray and Gottlieb, 1993; Turetsky et al., 1993). However, a clonal line of human neurons that exhibit excitotoxicity would be ideal for these investigations.

NT2 cells are a clonal human teratocarcinoma cell line that can be manipulated following treatment with retinoic acid to yield $>99 \%$ pure cultures of terminally differentiated NT2-N neurons (Lee and Andrews, 1986; Pleasure et al., 1992). NT2-N cells elaborate processes that differentiate into axons and dendrites and express neuronal cytoskeletal proteins, neuronal secretory markers, and neuronal cell surface markers (Pleasure et al., 1992). Both NMDA and non-NMDA glutamate receptor channels have been identified electrophysiologically (Younkin et al., 1993) and mRNAs for several subtypes of glutamate receptor have been detected (Younkin et al., 1993; Hardy et al., 1994). Most importantly, glutamate is toxic to differentiated NT2-N cells (Younkin et al., 1993). The goals of this study were to demonstrate that NT2-N cells exhibit a robust excitotoxic response and use these cells to explore the molecular mechanisms underlying excitotoxicity in human neurons. 


\section{Materials and Methods}

Cell culture. Exponentially growing NT2 cells were maintained in OptiMEM-I (GIBCO, Gaitherburg, MD) supplemented with 5\% (v/v) fetal bovine serum (FBS) and penicillin/streptomycin (P/S) as previously described (Andrews, 1984). These cells were split 1:3 twice a week. To induce terminal differentiation, $2 \times 10^{6} \mathrm{NT} 2$ cells were seeded in a 75 $\mathrm{cm}^{2}$ flask and treated with $10 \mu \mathrm{M}$ retinoic acid twice weekly for 5 weeks. The cells were then split 1:6 and replated in Dulbecco's modified Eagle's medium/high glucose (DMEM/HG) with $10 \%$ FBS and P/S. Two days later, the differentiated NT2 (NT2-N) cells were separated from non-neuronal cells by first treating the cells with trypsin and then mechanically dislodging them by gently striking the flasks. Semipurified NT2-N cells were plated on Matrigel (Collaborative Research, Bedford, MA) coated culture plates or flasks and maintained in DMEM/HG with $5 \%$ FBS, P/S and fed once a week. Matrigel is a basement membrane extract that includes collagen, laminin, and nidogen (Kleinman et al., 1986). For the first 3 weeks after plating, the NT2-N cells were treated with the mitotic inhibitors $1-\beta$-D-arabinofuranosylcytosine $(1 \mu \mathrm{M})$, fluorodeoxy-uridine $(10 \mu \mathrm{M})$ and uridine $(10 \mu \mathrm{M})$ to inhibit the division of non-ncuronal cclls.

Assays for cell survival. For these assays the cultures were prepared in 96 well plates. One line of eight wells was used for every treatment. The NT2-N cells were exposed for $15 \mathrm{~min}$ to various treatments in control salt solution (CSS), containing $110 \mathrm{mM} \mathrm{NaCl}, 5.4 \mathrm{mM} \mathrm{KCl}, 0.8$ $\mathrm{mM} \mathrm{MgCl}, 1.8 \mathrm{mM} \mathrm{CaCl}_{2}, 15 \mathrm{~mm} \mathrm{NaHCO}, 15 \mathrm{~mm}$ glucose, $15 \mathrm{~mm}$ $N$-(2-hydroxyethyl)-1-piperazineethane-sulfonic acid (HEPES), and 10 mM $N$-(2-hydroxyethyl)-piperazine- $N^{\prime}$-[3-propane]-sulfonic acid (EPPS), with $50 \mu \mathrm{m}$ glycine at $\mathrm{pH} 8.0$. The cells were washed three times with CSS before the treatment. The treatment was initiated in the culture hood and the cells were transfered to a $37^{\circ} \mathrm{C}$ incubator lacking $\mathrm{CO}_{2}$ for the next $15 \mathrm{~min}$. The cells were washed three times after the treatment and maintained in CSS for $20-24 \mathrm{hr}$ in a $37^{\circ} \mathrm{C}$, humidified $5 \% \mathrm{CO}_{2}$ incubator. The $\mathrm{pH}$ of the CSS declined steadily and predictably in the $5 \% \mathrm{CO}_{2}$ environment, reached 7.4 in $40 \mathrm{~min}$ and rcmained stable at 7.4 for $24 \mathrm{hr}$. Each experiment was performed at least three times. For studies of the effects of $\mathrm{pH}$, toxicity assays were done in CSS without $\mathrm{HCO}_{3}$ and the incubations were done in an incubator without $\mathrm{CO}_{2}$.

Lactate dehydrogenase. Release of the cytoplasmic enzyme lactate dehydrogenase (LDH) was used as a measure of cell viability; 20-24 $\mathrm{hr}$ after treatments, specimens from the culture media were analyzed for the amount of $\mathrm{LDH}$ released by the dead cells. LDH assays were done in duplicate for each sample and LDH activity was measured using a colorimetric assay (LDH diagnostic kit, Sigma) based on the conversion of pyruvic acid to lactic acid by LDH in the presence of nicotinamide adenine dinucleotide, reduced (NADH) (Cabaud and Wroblewski, 1958). The assay was performed according to the manufacturer's protocol. The LDH values have been described as B-B units/ml (Cabaud and Wroblewski, 1958), and where appropriate, have been scaled to the mean LDH release caused by $1 \mathrm{~mm}$ glutamate.

Cell counting. To determine the extent of cell death, pictures of 1012 adjacent microscopic fields in representative cultures were taken just before and $24 \mathrm{hr}$ after the glutamate treatment. Live cells in each picture were visually counted. The difference in number of viable cells before and $24 \mathrm{hr}$ after glutamate exposure divided by the total number of cells before glutamate exposure is presented as percent cell death.

Time-lapse videomicroscopy. Cells were cultured in $75 \mathrm{~cm}^{2}$ flasks coated with Matrigel as described previously. During the recording session, cells were positioned on the stage of a Nikon Diaphot microscope and maintained at $37^{\circ} \mathrm{C}$ by having the entire apparatus in a temperaturecontrolled warm room. Videomicroscopy was performed using a Panasonic video camera with Newvicon tube and Panasonic AG-6050 timelapse video recorder. Images were enhanced using an Image $1 / \Lambda \mathrm{T}$ digital image processing system (Ivins et al., 1991).

NMDA receptor binding. The binding assays were carried out as described by Williams et al. (1992). To prepare membranes for ${ }^{125}$ I-MK801 binding assays cultures of different ages were washed three times with CSS. Cells were removed from the culture dishes with a cell scraper and homogenized in $25 \mathrm{ml}$ (per $10 \mathrm{~cm}$ dish) of buffer A $55 \mathrm{~mm}$ ethylenediaminetetraacetic acid (EDTA), pH 7.0 with $\mathrm{KOH}$ ] with a polytron. Homogenates were centrifuged at $100,000 \times g$ for $30 \mathrm{~min}$. Pellets were resuspended with homogenizer in $40 \mathrm{ml}$ of buffer $\mathrm{A}$ and incubated for $30 \mathrm{~min}$ at $32^{\circ} \mathrm{C}$. The homogenates were centrifuged, resuspended and incubated as described above three more times. The final pellets were resuspended in buffer B ( $20 \mathrm{~mm}$ HEPES, $1 \mathrm{~mm}$ EDTA, pH 7.4 with $\mathrm{KOH}$ ) at a concentration of $200-500 \mu \mathrm{g}$ protein $/ \mathrm{ml}$ and stored at $-70^{\circ} \mathrm{C}$ until used (within 2 weeks). Binding assays were carried out in polypropylene tubes containing membranes prepared from the cultured cells (40-50 $\mu \mathrm{g}$ protein), $0.13 \mathrm{nM}{ }^{125} \mathrm{I}-\mathrm{MK}-801$ (specific activity $2200 \mathrm{Ci} / \mathrm{mm}$ ) $100 \mu \mathrm{M}$ glutamale, $100 \mu \mathrm{M}$ glycine, and $30 \mu \mathrm{m}$ spermine. Nonspecific binding was determined with $10 \mu \mathrm{M}(+)$-MK-801 Rat hippocampal tissue prepared in the same way as described was used as a positive control.

Radioimmunoassays for cyclic gaunosine monophosphate (GMP). Rat cerebellar slices $(0.4 \mathrm{~mm}$ thick) prepared according to Garthwaite and Garthwaite (1987) or NT2-N cells grown in 12 well plates were preincubated for $1 \mathrm{hr}$ with nitric oxide synthase (NOS) inhibitors and were exposed to $1 \mathrm{~mm}$ glutamate for $2 \mathrm{~min}$ in Krebs-Henseleit buffer (Bredt and Snyder, 1989). The agonist stimulation was terminated by addition of an ice-cold $1: 1(\mathrm{vol} / \mathrm{vol})$ solution of $0.1 \mathrm{M} \mathrm{HCl}$ and ethanol. Samples were sonicated and centrifuged for $20 \mathrm{~min}$ at $2500 \times \mathrm{g}$. The cGMP content of the supernatants was determined by radioimmunoassay (NEN-Du Pont kit cat. no. NEX-133).

NADPH diaphorase staining for NOS. The presence of nitric oxide synthase was determined by measuring NADPH diaphorase activity. NT2-N cells and rat primary cultured cortical neurons, grown in $5 \mathrm{~cm}$ culture dishes were fixed by incubation with $3 \%$ paraformaldehyde in PBS (0.1 M PO 4 saline, pH 7.4) for 5 min. After two washes for $1 \mathrm{~min}$ each with PBS, the cells were incubated with $4 \mathrm{ml}$ of PBS containing $8 \mathrm{mg}$ NADPH, $3.6 \mathrm{mg}$ nitro blue tetrazolium and $0.48 \mathrm{ml}$ dimethyl sulfoxide. The reaction was terminated by two washes for $1 \mathrm{~min}$ each at times chosen by inspection of trial dishes. The cells were then counterstained in neutral red for $1 \mathrm{~min}$.

Data analysis. Concentration-response curves for inhibition of toxicity were fit to the data points using the equation $E=E_{0} /[1+(L$ $\left.\left.I C_{\mathrm{So}}\right)^{n}\right]+\mathrm{NS}$, where $L$ is the concentration of inhibitor, $E_{0}$ is the level of toxicity produced by glutamate in the absence of inhibitor, $I C_{50}$ is the concentration at which a half-maximal inhibition is produced, $n$ is the Hill coefficient and NS is the level of toxicity produced in the presence of a maximally effective concentration of inhibitor. The group $t$ test was used to determine significant differences between two groups. Analysis of variance (ANOVA) followed by Dunnett's or NewmanKeul's test were used to determine significant differences between more than two groups.

\section{Results}

Pharmacological characterization of excitotoxic response in NT2-N cells

The excitotoxic response elicited by glutamate in NT2-N cells was measured using the release of $\mathrm{LDH}$ and cell counting. In cells grown for 5-6 weeks after purification and plating, glutamate-induced toxicity was concentration-dependent with an $E C_{50}$ of $10 \mu \mathrm{M}$ and an eightfold increase in $\mathrm{LDH}$ release produced by $1 \mathrm{~mm}$ glutamate (Fig. 1A). Similar to rat neurons in primary culture, the toxic response to glutamate occurred rapidly, with significant damage produced within 5 min and maximal toxicity observed after a 15 min exposure (Fig. $1 B$ ). The time course of $\mathrm{LDH}$ release after glutamate removal was markedly biphasic. The extracellular concentration of LDH increased steadily for approximately $10 \mathrm{hr}$ and then increased more rapidly until reaching a plateau at $16 \mathrm{hr}$ (Fig. 2). Glutamate toxicity required the presence of extracellular calcium and it was completely blocked if extracellular calcium was not present during glutamate exposure (Fig. 3). The toxicity produced by $1 \mathrm{~mm}$ glutamate was inhibited by $\mathrm{MK}-801$ in a dose-dependent manner with an $I C_{50}$ of $78 \mathrm{nM}$, indicating that the toxicity resulted from stimulation of NMDA receptors (Fig. 4). A 15 min exposure to NMDA itself produced a dose-dependent increase in toxicity with a maximum effect at $1 \mathrm{~mm}$ (Fig. 5A). The maximal toxicity produced by NMDA was less than that produced by glutamate, suggesting that stimulation of other subtypes of glutamate receptors may augment the response to stimulation of NMDA receptors. However, coincubation with agonists selective for non-NMDA subtypes of glutamate receptors, that is, $( \pm)$ - $\alpha$-amino-3-hydroxy-5methylisoxazole-4-propionic acid (AMPA), kainate or quisqual- 

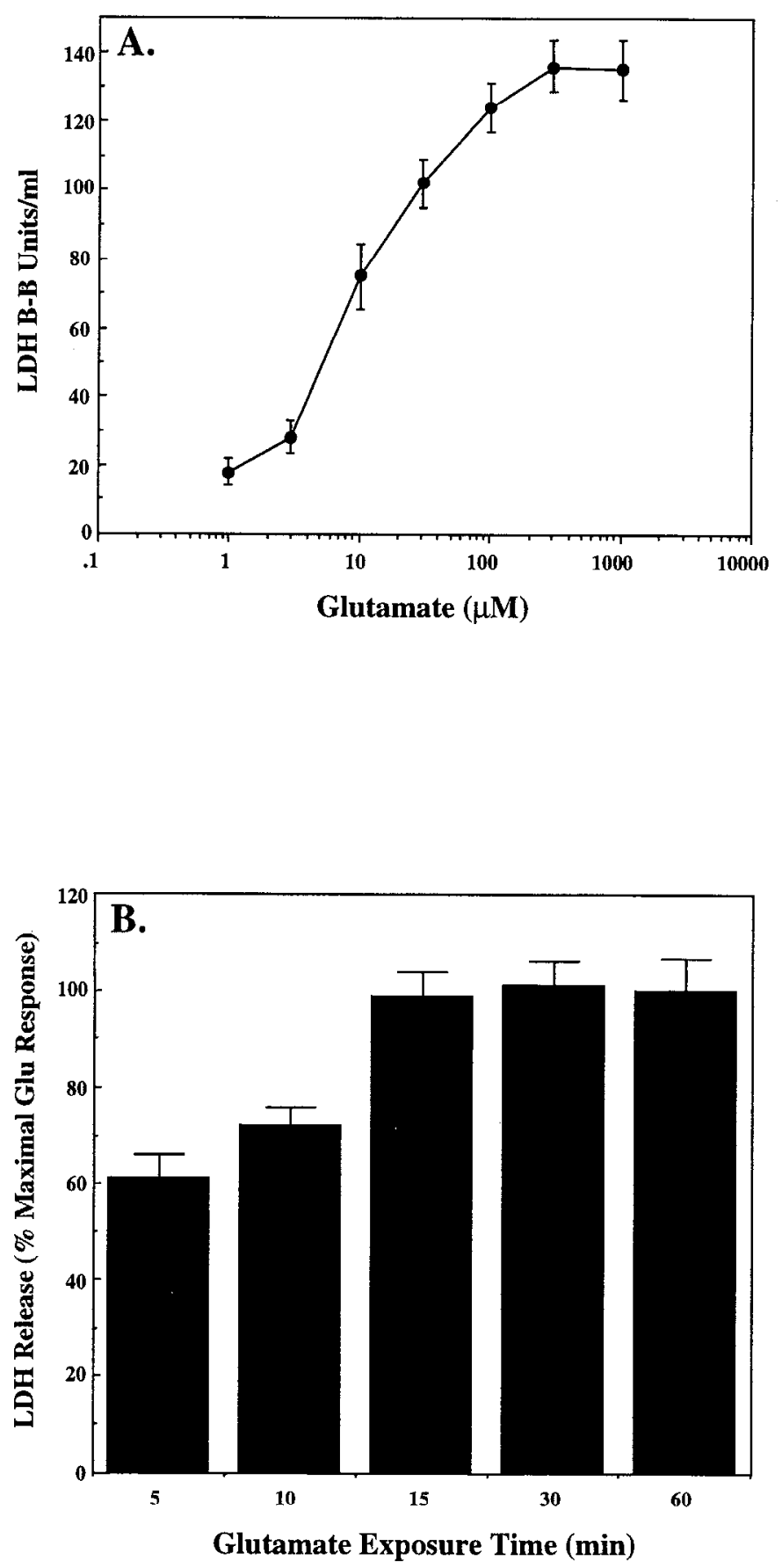

Figure 1. Short exposure to glutamate produces concentration-dependent toxicity in NT2-N cells. $A$, Six week old cells were exposed to increasing concentrations of glutamate for $15 \mathrm{~min}$. Glutamate produced a concentration-dependent toxicity with an $E C_{50}$ of $10 \mu \mathrm{M}$. Each point is the mean \pm SEM of 8 determinations representative of five experiments. $B$, Cells were exposed to $1 \mathrm{~mm}$ glutamate for increasing periods of time. Maximal toxicity to glutamate was produced with a 15 min exposure. Each bar is the mean \pm SEM of eight determinations representative of three experiments.

ate, failed to increase the maximal toxicity produced by NMDA (Fig. 5B). A 15 min exposure to AMPA, kainate or quisqualate alone did not elicit a toxic response but a $24 \mathrm{hr}$ exposure to these agonists produced a concentration-dependent increase in toxicity that peaked at $60 \%, 80 \%$, and $90 \%$ of maximal glutamate toxicity, respectively (Fig. 6A-C). This is consistent with

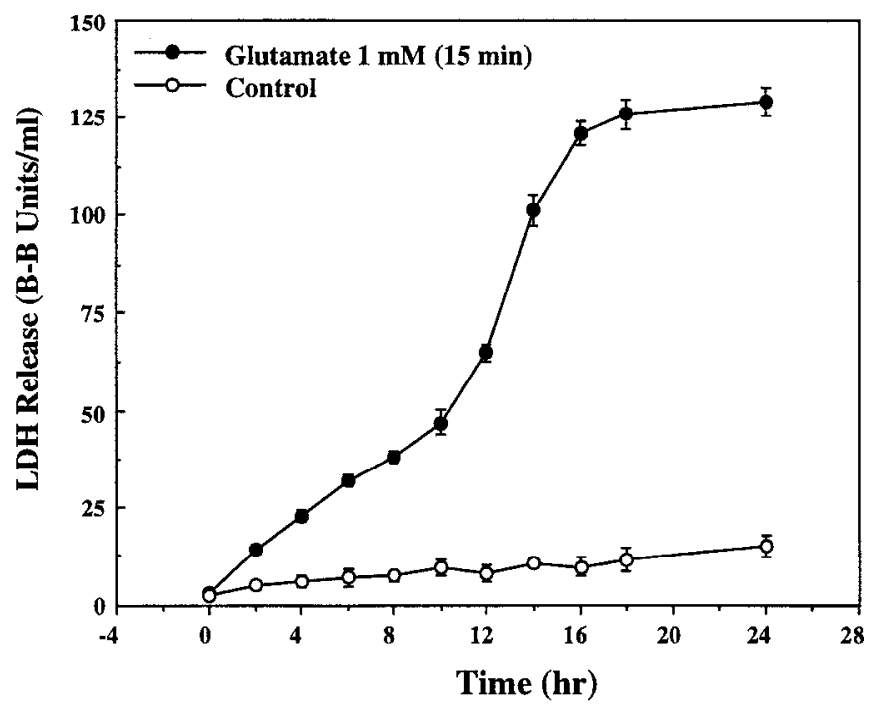

Figure 2. Time course of release of LDH after glutamate exposure. Cells were exposed to $1 \mathrm{~mm}$ glutamate for $15 \mathrm{~min}$ and samples for LDH assays were collected at the specified times. Each point is the mean \pm SEM of eight determinations representative of three experiments.

the report that these cells express mRNA for AMPA/kainate receptors (Hardy et al., 1994). MK-801 did not inhibit the toxicity caused by prolonged exposure to AMPA or kainate but partially inhibited the toxicity caused by quisqualate (Fig. 6C). Trans$( \pm)$-1-amino-1,3-cyclopentanedicarboxylic acid ( $t$-ACPD), a selective agonist for metabotropic receptors, did not cause any toxicity following a $24 \mathrm{hr}$ exposure (Fig. 6D).

\section{Effect of cell maturity on NMDA receptor expression and sensitivity to glularriate}

The toxic response to glutamate increased as the cells matured, with very little toxicity detected 2 weeks after plating and in-

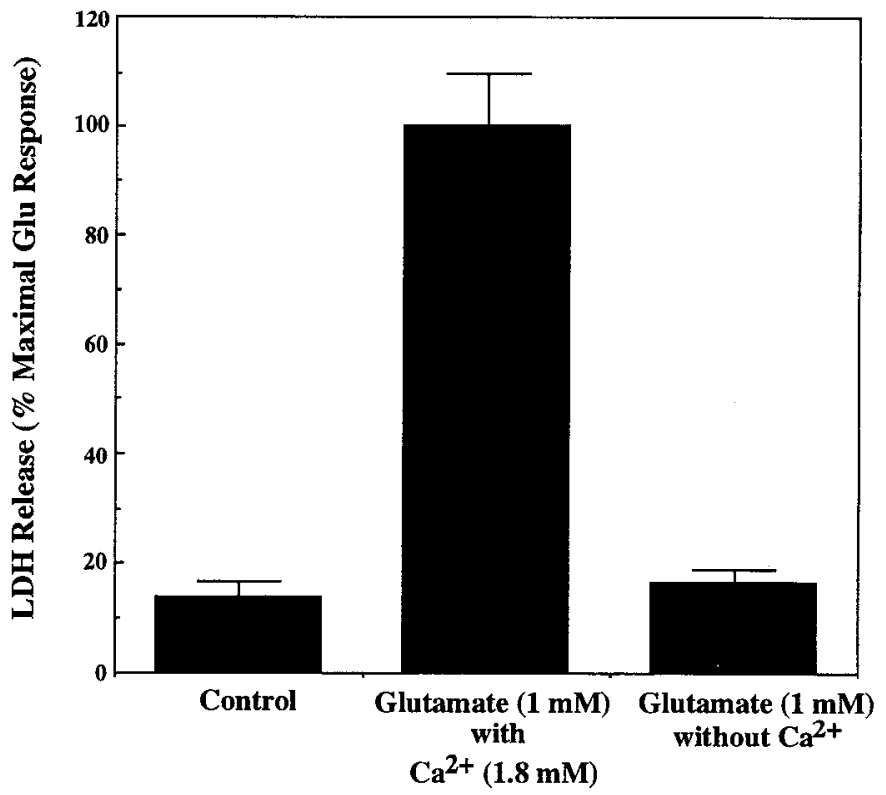

Figure 3. Glutamate toxicity is dependent on extracellular calcium. Cells were exposed to $1 \mathrm{~mm}$ glutamate for $15 \mathrm{~min}$ in the presence or absence of extracellular calcium. Glutamate toxicity was essentially eliminated in the absence of calcium. Each bar is the mean \pm SEM of eight determinations representative of three experiments. 


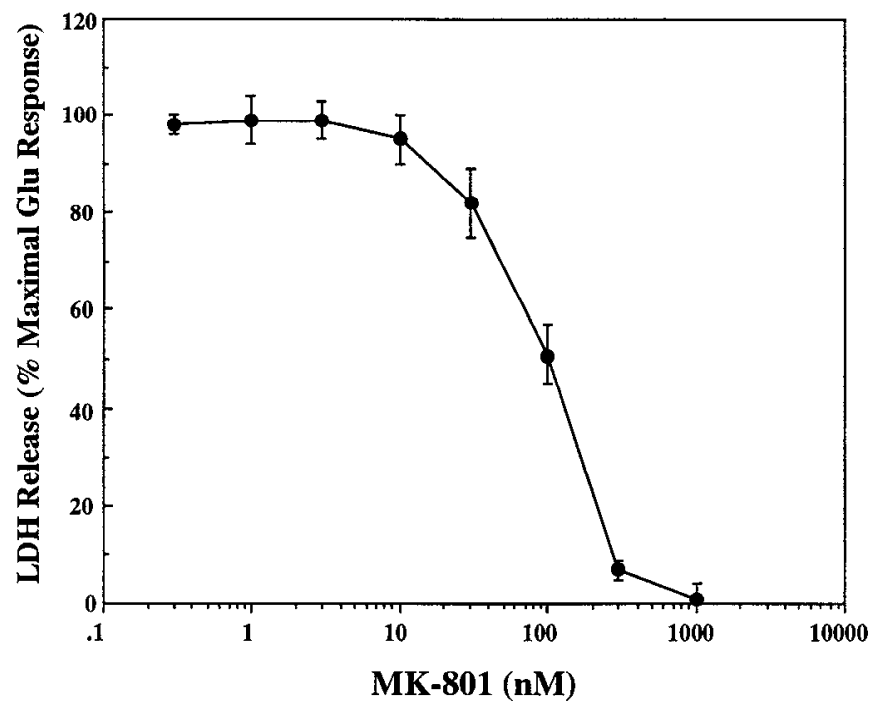

Figure 4. MK-801 completely blocks glutanate toxicity. Cells were exposed to increasing concentrations of selective NMDA receptor antagonist MK-801 in the presence of $1 \mathrm{mM}$ glutamate for $15 \mathrm{~min}$. MK801 inhibited glutamate toxicity with an $\mathrm{IC}_{50}$ of $78 \mathrm{nM}$. Each point is the mean \pm SEM of eight determinations representative of four experiments.

creasing toxicity measured between 3 and 8 weeks after plating (Fig. 7A). The sensitivity to glutamate increased markedly between weeks 2 and 3 , suggesting that some critical change occurs to the cells during this period. Significant changes in the morphology of the cells occur during the first 3 weeks. Upon plating, the cells begin to sprout and grow processes within one day. The number of processes and connections increases steadily with age (Fig. 8). The majority of non-neuronal cells in the culture die between weeks 1 and 3 without any apparent loss of NT2-N cells. Between weeks 2 and 3, the processes elaborated by the NT2-N cells begin to arborize resulting in a significant increase in the density of visible processes. Process elongation and arborization continues to increase with age, resulting in a complex network of processes in the mature cultures (Fig. 8). There appears to be minimal loss of NT2-N cells between weeks 1-5; after this time there is a slowly increasing loss of cells. Despite the loss of cells associated with aging, NT2-N cells have survived in culture for up to 4 months. The expression of NMDA receptors by NT2-N cells also changes with age. The number of NMDA receptors labeled with ${ }^{125} \mathrm{I}-\mathrm{MK}-801$ in membranes prepared from NT2-N cells increases gradually with age (Fig. 7B). There appears to be a significant correlation between NMDA receptor density and the toxic response to glutamate. The density of NMDA receptors expressed by NT2-N cells is approximately 10-fold less than that measured in mature rat hippocampal membranes (data not shown).

\section{Morphological changes associated with excitotoxic cell death}

Expression of toxicity in NT2-N cells is associated with a cluster of morphological changes associated with necrotic cell death that closely mimic those observed in primary cultured neurons. Changes in cell morphology associated with exposure to glutamate were monitored with time-lapse videomicroscopy (Fig. 9). Typically, the cell body begins to swell immediately after exposure to glutamate. By $15 \mathrm{~min}$, a phase-dark band forms at or near the perimeter of the cell body. Over the next $6-8 \mathrm{hr}$, this band steadily contracts and ultimately forms a phase-bright body
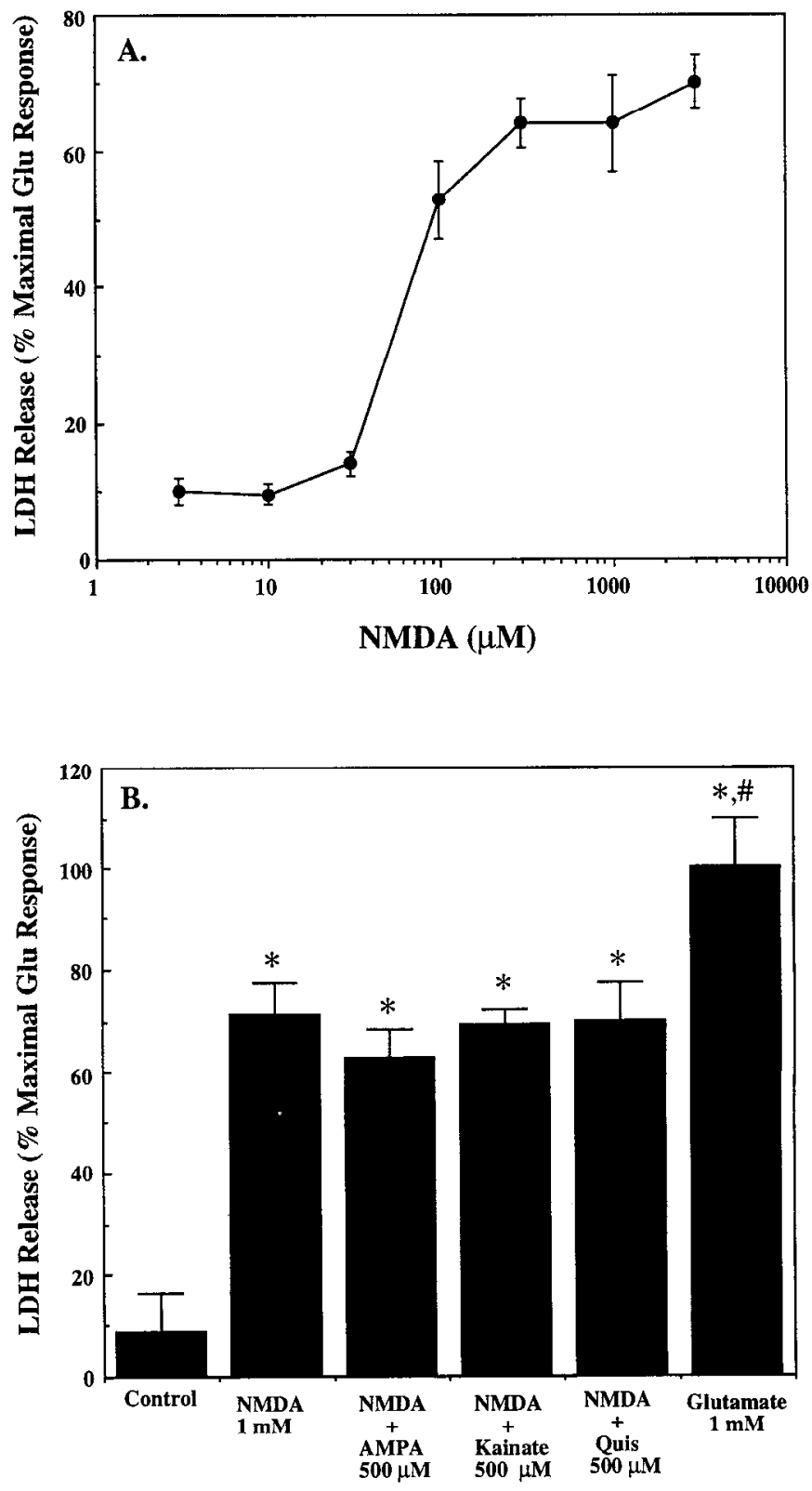

Figure 5. NMDA produces concentration-dependent toxicity in NT2-N cells that is not enhanced by non-NMDA agonists. $A$, Cells were exposed to increasing concentrations of NMDA for $15 \mathrm{~min}$. NMDA produced a concentration-dependent toxicity with an $E C_{50}$ of $62 \mu \mathrm{M}$ but the maximum toxicity produced by NMDA was less than that of glutamate. Each point is the mean \pm SEM of eight determinations representative of three experiments. $B$, Cells were treated for $15 \mathrm{~min}$ with 1 mM NMDA in the presence of agonists selective for different nonNMDA glutamate receptors. None of the agonist combinations produced the same level of toxicity as $1 \mathrm{~mm}$ glutamate. Each bar is the mean \pm SEM of eight determinations representative of three experiments. * indicates significant difference from control at $p<0.05$. \# indicates significant difference from NMDA (1 mM) at $p<0.05$.

within the center of the swollen cell that appears to contain most of the intracellular organelles. Between 2 and $4 \mathrm{hr}$ there is intense neurite outgrowth. At 10-12 hr after glutamate exposure, the cell membrane disappears from view as if it had burst. During this period some of the dendritic processes actively retract resulting in the translocation of associated cell bodies. These phenomenon continue to occur up to $24 \mathrm{hr}$ after glutamate ex- 

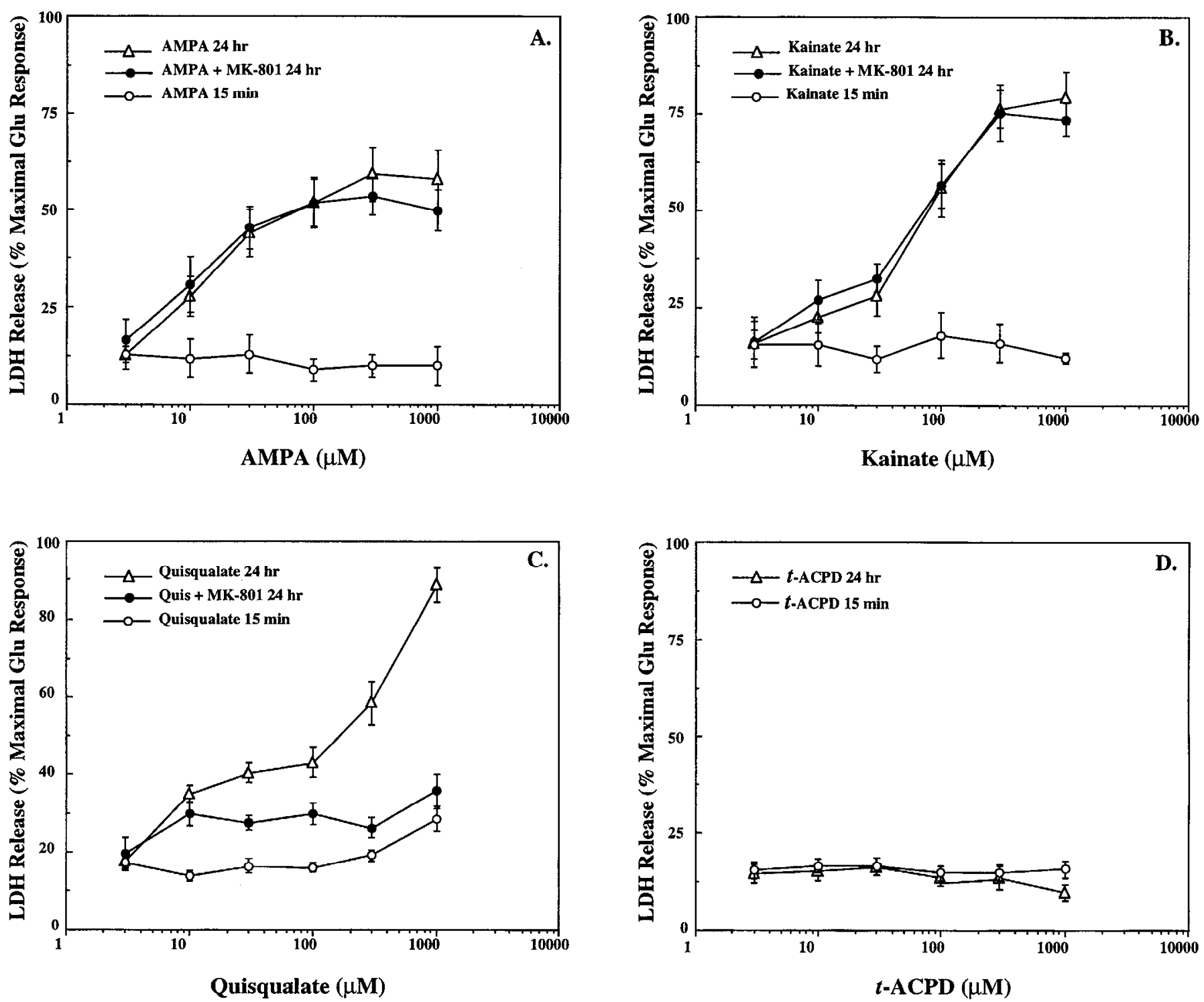

Figure 6. Prolonged exposure to some non-NMDA agonists produces toxicity. Cells were exposed to increasing concentrations of non-NMDA agonists either for $15 \mathrm{~min}$ or for $24 \mathrm{hr}$ in the presence or absence of $1 \mu \mathrm{M}$ MK-801. A $15 \mathrm{~min}$ exposure to AMPA $(A)$, kainate $(B)$, quisqualate $(C)$, or trans-ACPD $(D)$ was not toxic according to one-way ANOVA. In contrast, a $24 \mathrm{hr}$ exposure to AMPA or kainate produced dose-dependent toxicity that peaked at $60 \%$ and $80 \%$ of maximal glutamate toxicity, respectively. This toxicity was not blocked by MK- 801 . A 24 hr exposure to quisqualate also produced dose-dependent toxicity that reached $90 \%$ of maximal glutamate toxicity at a concentration of 1 mm. The toxicity produced by chronic exposure to quisqualate was partially inhibited by MK-801. The selective metabotropic agonist trans-ACPD was not toxic following prolonged exposure. Each point is the mean \pm SEM of eight determinations representative of three experiments.

posure. Cell counting revealed that after $24 \mathrm{hr}, 80-90 \%$ of the cells were dead (Fig. 10).

\section{Modulation of the glutamate-mediated toxicity}

The NMDA receptor can be modulated by several factors including $\mathrm{pH}$, glycine, and polyamines, and these factors have been shown to alter the excitotoxic response to glutamate and NMDA. Similar to results obtained in primary cultured neurons, lowering the $\mathrm{pH}$ reduced the toxicity produced by $1 \mathrm{mM}$ glutamate in NT2-N cells (Fig. 11A). The toxic response was completely eliminated when the $\mathrm{pH}$ was reduced to 7.0 or below. In order to enhance the signal, all other treatments were carried out at $\mathrm{pH} 8.0$. Following the treatment, the $\mathrm{pH}$ returned to 7.4 in the incubator at $5 \% \mathrm{CO}_{2}$ within $40 \mathrm{~min}$ and the temporary alkaline $\mathrm{pH}$ had no obvious harmful effect on the cells. The gly- cine site antagonist, 7-chlorokynurenic acid completely inhibited glutamate-induced toxicity at a concentration of $300 \mu \mathrm{M}$. This inhibition was reversed by $200 \mu \mathrm{M}$ glycine (Fig. $11 B$ ) indicating that 7-chlorokynurenic acid was blocking the glycine site but not the glutamate site on the NMDA receptor. Administration of the polyamine agonist spermidine increased the toxicity produced by a submaximal dose (15 $\mu \mathrm{M})$ of glutamate (Fig. 12A). Conversely, the putative polyamine antagonist ifenprodil inhibited the toxicity produced by a maximally effective concentration of glutamate in a dose-dependent manner with an $I C_{50}$ of $0.6 \mu \mathrm{M}$ (Fig. 12B). The Hill coefficient of the ifenprodil inhibition curves was 1.0 or greater, consistent with an interaction at a single site. Williams et al. (1993) have recently reported that ifenprodil inhibits ${ }^{125} \mathrm{I}$ MK 801 binding and NMDA-induced currents at $\mathrm{NR} 1_{\mathrm{A}} / \mathrm{NR} 2_{\mathrm{B}}$ receptors with a similar $I C_{50}$. 

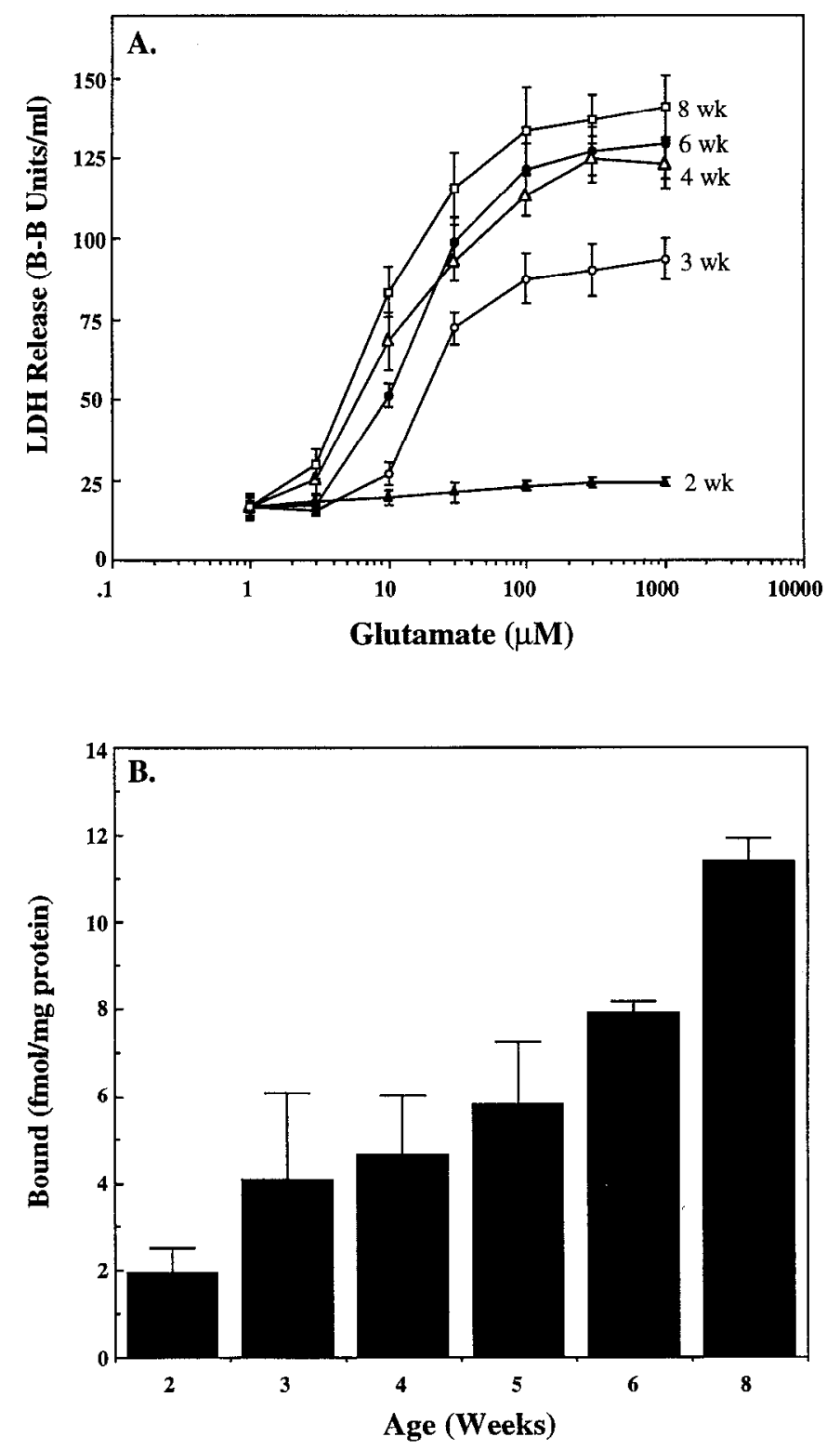

Figure 7. Sensitivity to glutamate toxicity and NMDA receptor expression in NT2-N cells increasc with maturation. A, Cells of various ages were exposed to increasing concentrations of glutamate for $15 \mathrm{~min}$. The maximum toxicity produced by glutamate increases as the cells mature but the $E C_{50}$ for glutamate does not appear to change after 3 weeks. Each point is the mean \pm SEM of eight determinations representative of three experiments. $B$, Membranes prepared from cells of various ages were labeled with ${ }^{125} \mathrm{I}-\mathrm{MK}-801(0.13 \mathrm{nM})$. The density of binding sites increased steadily as the cells matured. Each bar is the mean \pm SEM of three separate experiments performed in triplicate.

\section{Delayed rescue of $N T 2-N$ neurons}

One of the hallmarks of excitotoxicity observed in vivo and in vitro is an amplification stage that is initiated shortly after exposure to an excitotoxic agent and is independent of the triggering stimulus. A number of pharmacological and physiological interventions have been identified that are capable of rescuing cells from death during this period. Several of these approaches were utilized to demonstrate that NT2-N cells also exhibit this amplification component of excitotoxicity and can be rescued from death. In each experiment, 5-6 week old cells were exposed for $15 \mathrm{~min}$ to $1 \mathrm{~mm}$ glutamate and then washed three times with CSS. Up to $80 \%$ of the toxicity could be prevented by placing the cells in $\mathrm{Ca}^{2+}$-free media immediately after removal of glutamate. Placing the cells in $\mathrm{Ca}^{2+}$-free media $1 \mathrm{hr}$ after terminating the treatment with glutamate afforded very little protection (Fig. 13A). Addition of $1 \mu \mathrm{M} \mathrm{MK}-801$ within 5 min after removal of glutamate prevented $95 \%$ of the toxicity. Later applications of MK-801 were less effective indicating that the extent of protection was directly related to the length of time that elapsed between removal of glutamate and addition of MK801. No detectable protection was observed when MK-801 was added $1 \mathrm{hr}$ after terminating the treatment with glutamate (Fig. $13 B$ ). To determine whether this phenomenon involved the interaction of glutamate with the recognition site on the NMDA receptor, the ability of the competitive antagonist ( \pm )-2-amino5-phosphonovaleric acid (AP-5) to rescue cells was tested. AP-5 was just as effective as MK-801 in preventing damage when administered within 5 min of exposure to glutamate and the time course of delayed rescue was virtually identical to that of $\mathrm{MK}$ 801 (Fig. 13C). It was also possible to rescue cells by altering the post-treatment $\mathrm{pH}$. When post-treatment $\mathrm{pH}$ was below 7.0, little or no glutamate-mediated toxicity was observed. Increasing the post-treatment $\mathrm{pH}$ above 7.0 increased the extent of glutamate-mediated damage (Fig. 14A,B). To determine how long the receptor must stay inhibited to observe rescuc, AP-5 was added to the media immediately after termination of glutamate exposure and then removed after different intervals of time. The presence of AP-5 resulted in a duration-dependent increase in the extent of rescue (Fig. 15). Complete rescue was observed when AP-5 was present for $1 \mathrm{hr}$ after removal of glutamate. This result demonstrates that the amplification phase of toxicity lasts for at least 1 hI in NT2-N cells.

\section{Role of nitric oxide (NO)}

Nitric oxide has been identified as a potential mediator of excitotoxicity in neuronal cells (Dawson et al., 1991, 1993). Exposure of NT2-N cells to the nitric oxide releasing compound S-nitroso-N-acetylpencillamine (SNAP) (3 mM) produced extensive cell death (Fig. 16A). However, coincubation and postincubation with the nitric oxide synthase inhibitors $\mathrm{N}^{\mathrm{G}}$-nitro-Larginine methylester $\mathrm{HCl}$ (L-NAME) and $\mathrm{N}^{\mathrm{G}}$-nitro-L-arginine (L-NOARG) to prevent the formation of nitric oxide had no effect on the extent of toxicity produced by $1 \mathrm{~mm}$ glutamate (Fig. 16B). Nitric oxide has also been shown to stimulate the formation of cGMP in neuronal tissue (Garthwaite and Garthwaite, 1988; East and Garthwaite, 1991). Glutamate-mediated increases in cGMP were observed in rat cerebellar slices and inhibitors of NOS completely blocked this response (Fig. 17, top). However, no glutamate-mediated increase in cGMP was detected in NT2-N cells (Fig. 17, bottom). NT2-N cells do have functional guanylate cyclase since SNAP produced an 11-fold increase in cGMP levels. When NT2-N cells were stained with NADPH diaphorase to detect nitric oxide synthase activity, no positive cells were detected (Fig. 18). The failure of nitric oxide synthase inhibitors to prevent glutamate toxicity and inability to detect functional nitric oxide synthase with NADPH diaphorase indicate that nitric oxide is not involved in glutamate-mediated toxicity in NT2-N cells.

\section{Discussion}

The excitotoxic response to glutamate exhibited by NT2-N neurons is remarkably similar to the response observed in primary cultured neurons. Induction is rapid, with maximum toxicity ob- 

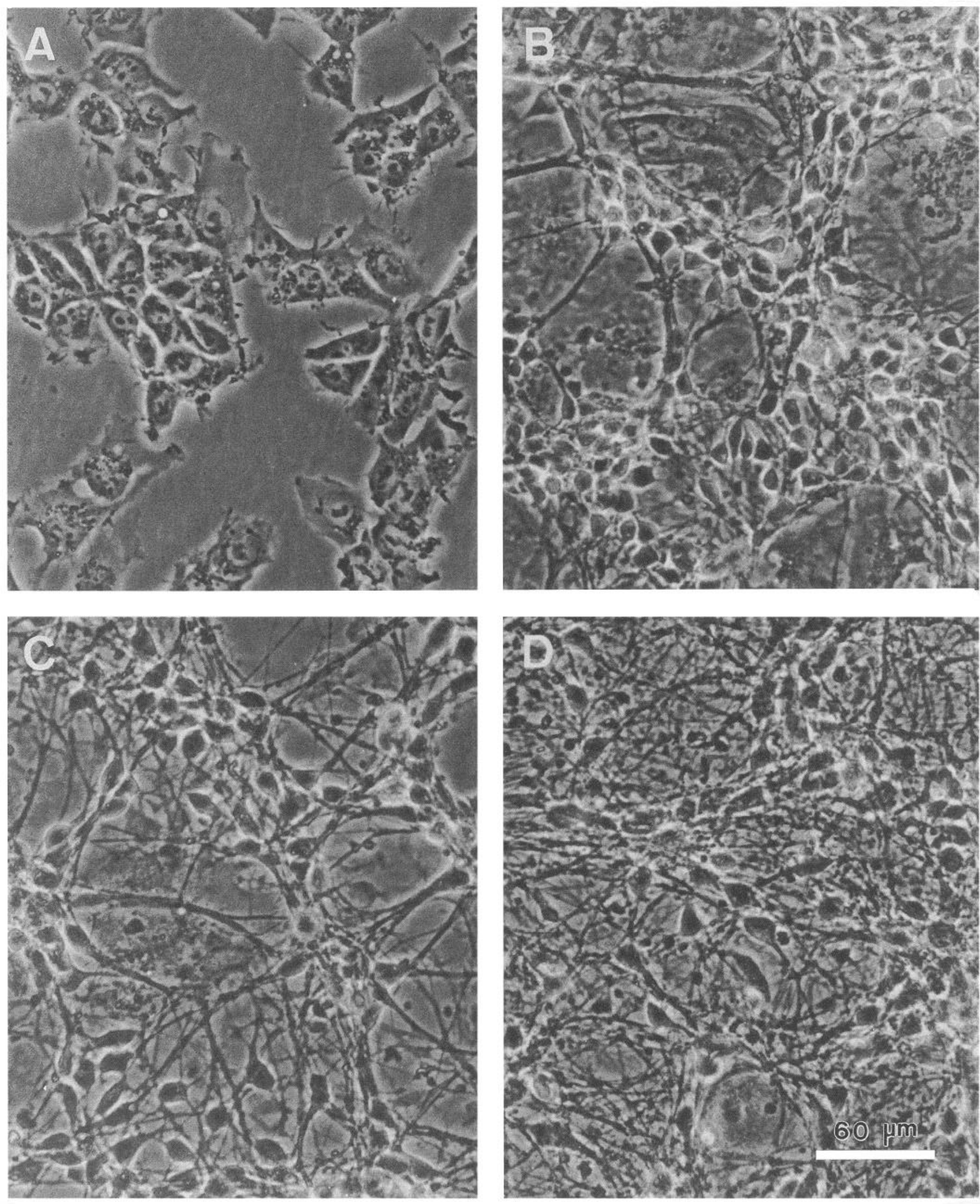

Figure 8. Morphological changes during maturation of NT2-N cells. A, Undifferentiated (NT2) tumor cells. $B$, NT2-N cultures one week after final plating. Neuronal processes are begining to develop. Some non-neuronal cells can be seen in the background. $C$, Three week old NT2-N cultures. The number of neuronal processes increases and most of the non-neuronal cells disappear. $D$, Five week old NT2-N neurons arborize extensively and form a dense network of processes. 

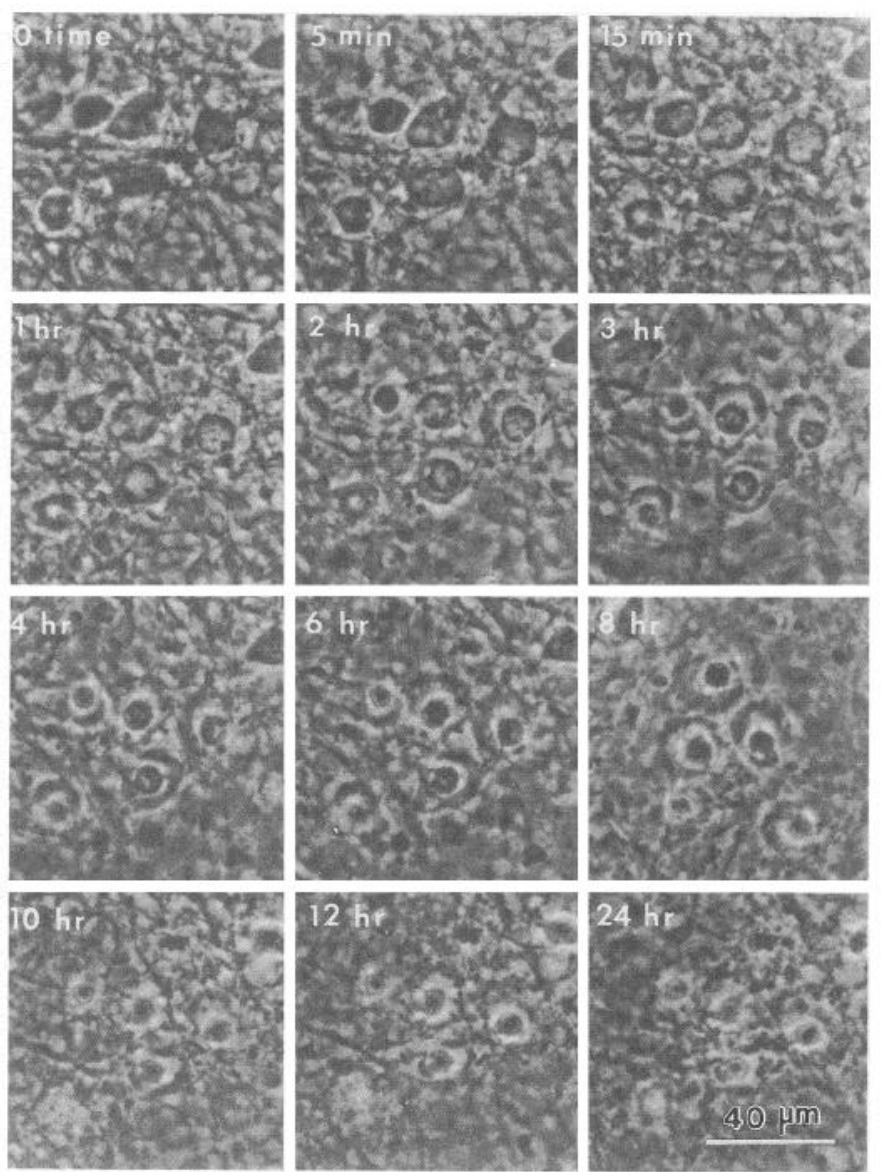

Figure 9. Morphological changes associated with excitotoxic cell death. Cells were exposed to $1 \mathrm{~mm}$ glutamate for $15 \mathrm{~min}$ and pictures vere taken from the begining of the exposure at specified time intervals. it $15 \mathrm{~min}$, cell bodies are highly swollen and a phase-dark band appears at the perimeter of the cells. This band steadily contracts over the next $6-8 \mathrm{hr}$ and forms a phase-bright body within the swollen cells. At 10$12 \mathrm{hr}$ the membrane disappears from view.

served within $15 \mathrm{~min}$ compared to 5 or $10 \mathrm{~min}$ in primary culture (Choi 1992). The $E C_{50}$ for glutamate toxicity corresponds to the $E C_{50}$ obtained in astrocyte-poor rather than astrocyte-rich primary cortical cultures (Rosenberg et al., 1992). This can be attributed to the absence of glutamate uptake by astrocytes and highlights the distinct advantage of this model system that responses are not confounded by the presence of multiple cell types. Glutamate toxicity is completely inhibited by selective NMDA antagonists, requires the presence of $\mathrm{Ca}^{2+}$ and glycine and can be prevented by lowering the $\mathrm{pH}$ to 7.0. Moreover, delayed rescue can be effected by a variety of manipulations including removal of $\mathrm{Ca}^{2+}$, lowering the $\mathrm{pH}$ and administration of NMDA-selective antagonists (Hartley and Choi, 1989; Manev et al., 1989; Levy and Lipton, 1990; Shalaby et al., 1992). The degree of rescue is directly related to the time elapsed between induction and administration of inhibitor, with little or no rescue observed more than one hour after removal of glutamate. Acute exposure to non-NMDA agonists did not produce toxicity, however, prolonged exposure to quisqualate, kainate, or AMPA produced dose-dependent toxicity analogous to that produced in primary cultured neurons (Koh et al., 1990). This observation indicates that the NT2-N cells express functional AMPA/kainate
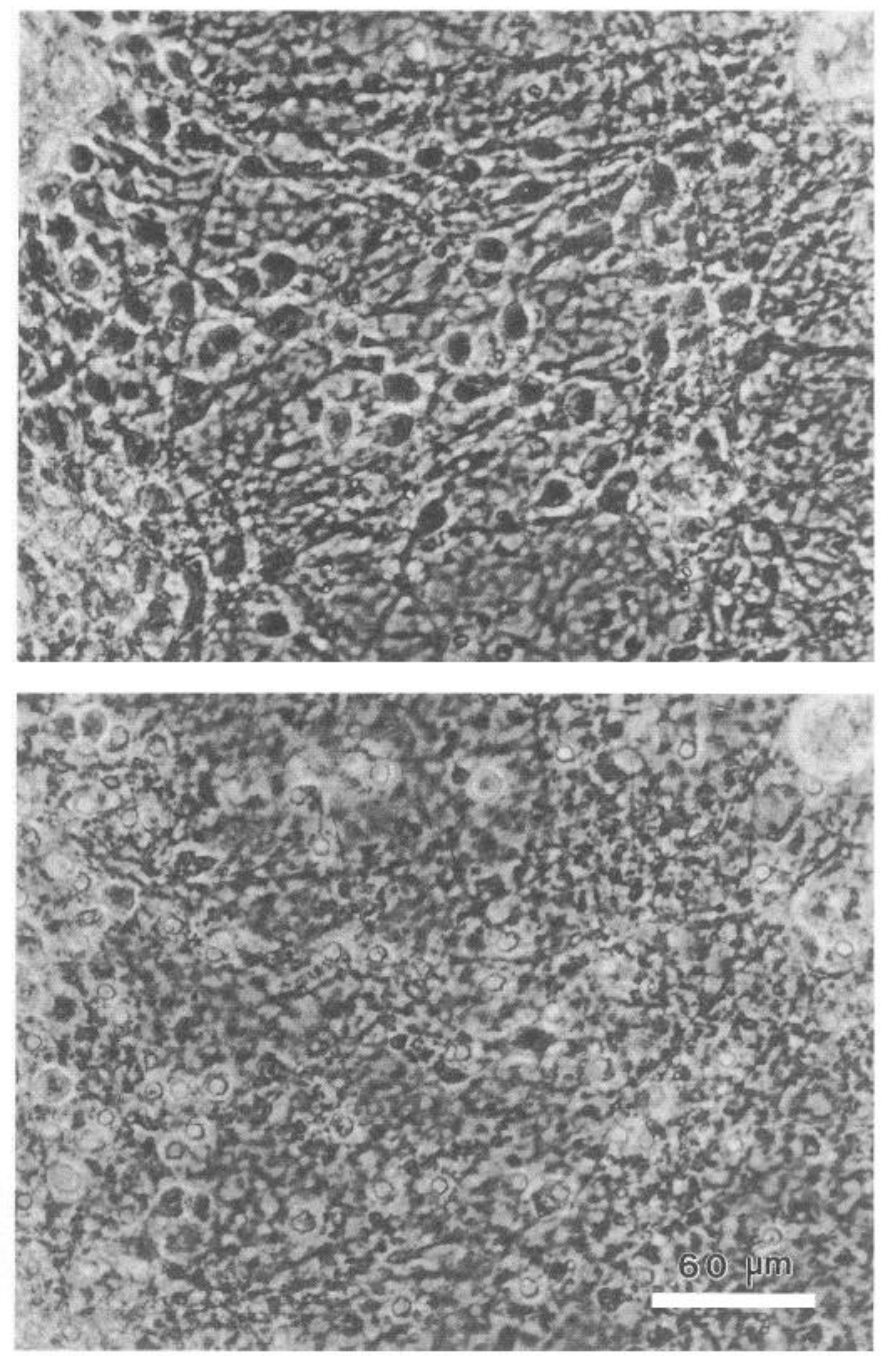

Figure 10. A brief glutamate exposure causes extensive cell death in NT2-N neurons. Cultures were exposed to $1 \mathrm{~mm}$ glutamate for $15 \mathrm{~min}$. Pictures were taken before and $24 \mathrm{hr}$ after the glutamate exposure. Cell counting revealed that glutamate exposure caused $85 \pm 5 \%$ cell death within $24 \mathrm{hr}$ in three separate experiments.

receptors and represent a unique model system in which to study slowly-triggered excitotoxicity.

One of the hallmarks of excitotoxicity is an amplification stage which can be disrupted by a variety of manipulations to effect the apparent rescue of cells from death (Choi, 1992). Virtually all of these manipulations center on the disruption of $\mathrm{Ca}^{2+}$ influx through NMDA receptor channels. Administration of the noncompetitive antagonist $\mathrm{MK}-801, \mathrm{Ca}^{2+}$ removal and lowering $\mathrm{pH}$ could all be effective if the NMDA receptor channel were somehow fixed in an open state. However, the ability of the competitive antagonist AP-5 to block amplification indicates that extracellular glutamate is required for this response. The source of glutamate during this amplification stage has not been determined. Postulated sources of glutamate in primary cultures include enhanced release from the presynaptic terminals, release from damaged neurons that lose their membrane integrity, inhibition of glial and neuronal uptake, and reversal of $\mathrm{Na}^{+}$-dependent glutamate transport (Kimelberg et al., 1990; Szatkowski et al., 1990; Choi, 1992). In pure cultures of NT2-N cells, uptake and release of glutamate from glial cells can be eliminated as a 

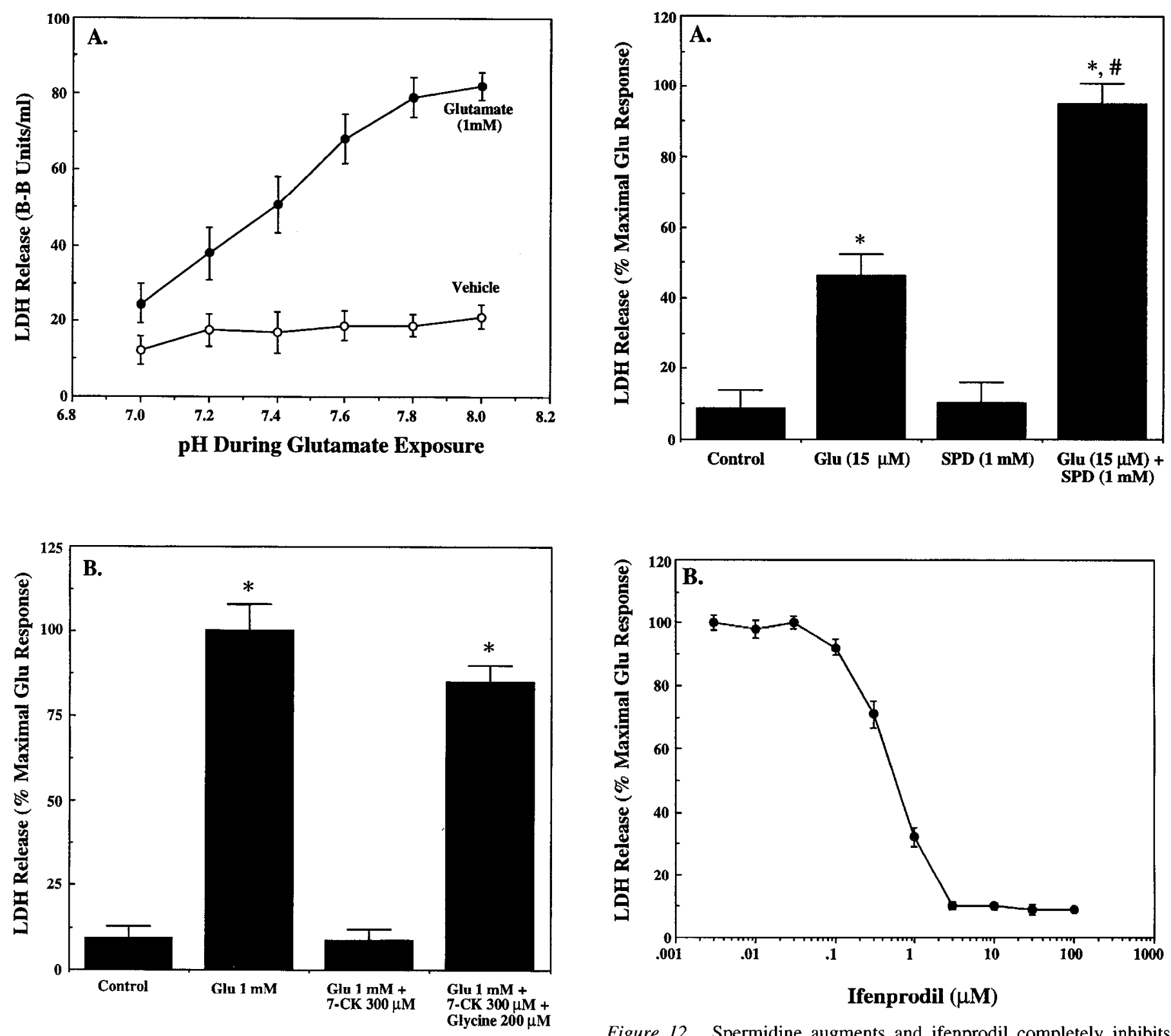

Figure 11. Glutamate toxicity is dependent on extracellular $\mathrm{pH}$ and glycine. $A$, Cells were treated with $1 \mathrm{~mm}$ glutamate at the specified $\mathrm{pH}$ values for $15 \mathrm{~min}$, washed, and then post-incubated at $\mathrm{pH} 7.5$. Glutamate toxicity was inhibited by decreasing the $\mathrm{pH}$ and little toxicity was observed at $\mathrm{pH}$ 7.0. In contrast, alkaline $\mathrm{pH}$ accentuated glutamate toxicity. Each point is the mean \pm SFM of eight determinations representative of four experiments. $B$, Cells were exposed to $1 \mathrm{~mm}$ glutamate with 7-chlorokynurenate $(7-C K)$ in the presence or absence of glycine for $15 \mathrm{~min}$. 7-Chlorokynurenate completely inhibited the glutamate toxicity at $300 \mu \mathrm{M}$. Addition of $200 \mu \mathrm{M}$ glycine restored the glutamate toxicity to near maximal levels. Each bar is the mean \pm SEM of eight determinations representative of three experiments. * indicales significant difference from control at $p<0.05$.

possibility. Moreover, discharge from damaged neurons is unlikely based on the time course of morphological changes and LDH release. Uptake of glutamate during treatment and release in the delayed phase by the neurons and efflux of glutamate due to reversal of transport are distinct possibilities (Szatkowski and Attwell, 1994). We have observed a robust $\mathrm{Na}^{+}$-dependent glutamate transport in the NT2-N cells (unpublished observation). NMDA is not transported by the glutamate transporter (Rosen-

Figure 12. Spermidine augments and ifenprodil completely inhibits glutamate toxicily. A, Cells were exposed to the polyamine agonist spermidine $(1 \mathrm{mM})$ for $15 \mathrm{~min}$ in the presence or absence of $15 \mu \mathrm{M}$ glutamate. Asterisk indicates a significant difference from untreated control and (\#) indicates a significant difference from glutamate $(15 \mu \mathrm{M})$ control at $p<0.05$. Each bar is the mean \pm SEM of eight determinations representative of three experiments. $B$, Cells were exposed to increasing concentrations of the putative polyamine antagonist ifenprodil for 15 min in the presence of $1 \mathrm{~mm}$ glutamate. Ifenprodil blocked glutamate toxicity with an $\mathrm{IC}_{50}$ of $0.6 \mu \mathrm{M}$. Each point is the mean $\pm \mathrm{SEM}$ of eight. determinations representative of three experiments.

berg et al., 1992) which could account for the inability of NMDA to produce the same extent of toxicity as glutamate in NT2-N cells, that is, the additional toxicity produced by glutamate could be due to uptake and rerelease.

The duration of the therapeutic window of opportunity appears to be very similar to that observed in primary cultured neurons (Choi, 1992; Shalaby et al., 1992), with blockade of NMDA receptors resulting in no protection if administered $1 \mathrm{hr}$ atter glutamate removal. Interestingly, the duration of vulnerability after glutamate washout is limited to $1 \mathrm{hr}$. Based on the 

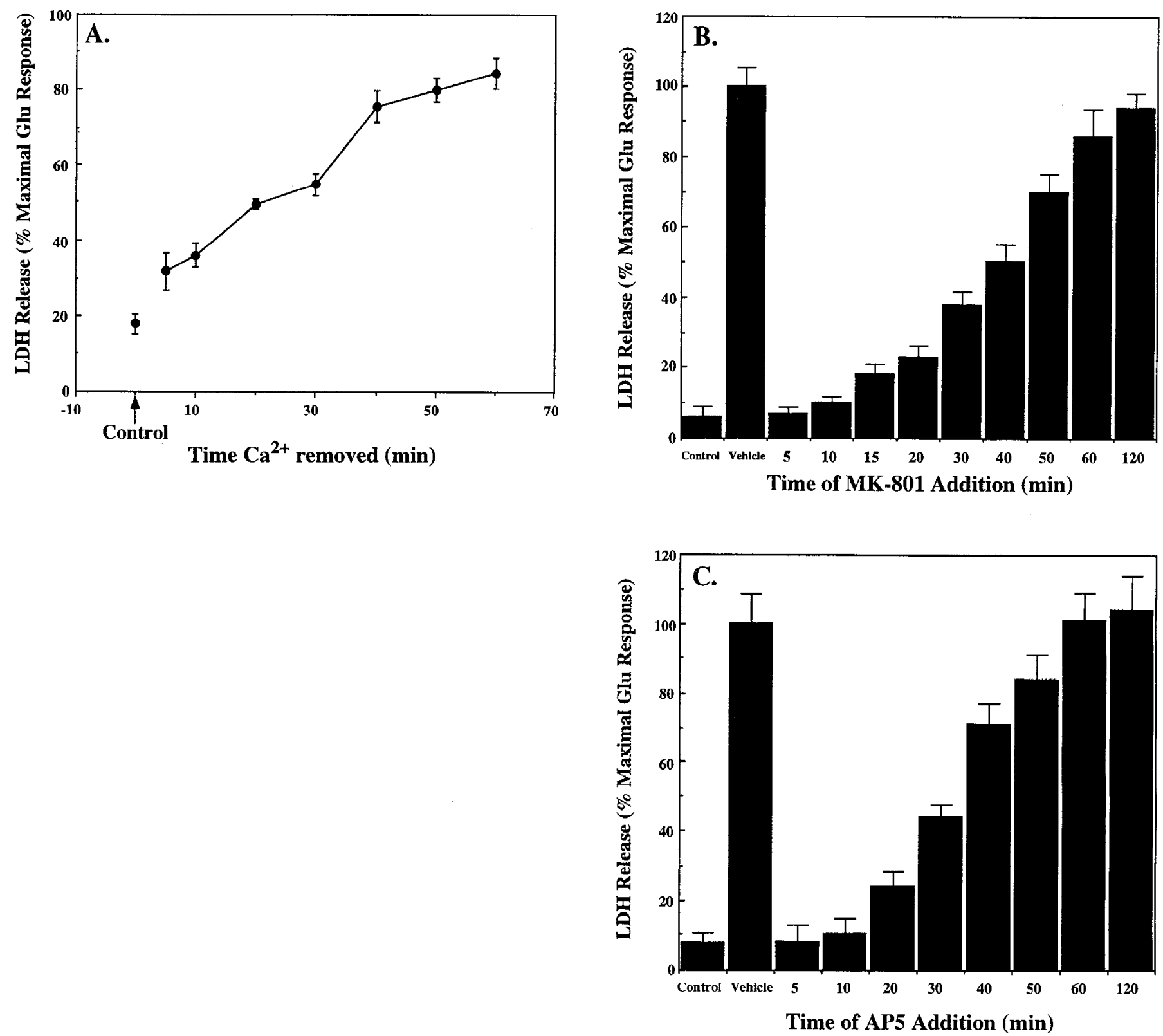

Figure 13. NT2-N cells can be rescued from death by removal of extracellular calcium or by blockade of NMDA receptors. $A$, Removal of extracellular calcium at different times after termination of a $15 \mathrm{~min}$ treatment with $1 \mathrm{~mm}$ glutamate resulted in a time-dependent rescue of cells from death. Extracellular calcium was restored to normal levels $3 \mathrm{hr}$ after glutamate washout. Each point is the mean \pm SEM of eight determinations representative of four experiments. $B$. Addition of the noncompetitive antagonist (MK-801) at various times after termination of glutamate treatment $(1 \mathrm{mM}, 15 \mathrm{~min})$ inhibited the toxic response. No protection was observed if MK-801 was introduced more than $1 \mathrm{hr}$ after the glutamate exposure was terminated. Each bar is the mean \pm SEM of eight determinations representative of three experiments. $C$, Addition of the competitive antagonist AP5 (1 mM) at various times after termination of glutamate treatment inhibited the toxic response. No protection was observed if AP5 was introduced more than $1 \mathrm{hr}$ after glutamate exposure was terminated. The degree of rescue was directly related to the time elapsed before adding the antagonist. Each bar is the mean \pm SEM of eight determinations representative of three experiments.

results obtained with AP-5, rescue of cells requires NMDA receptors to be inactivated for just $1 \mathrm{hr}$ to recover from the harm done by the glutamate exposure. One possible explanation for this temporal limit could be a decrease in the extracellular concentration of glutamate; however, this is not what we have observed (unpublished observations). Alternatively, NMDA receptors may no longer be responsive to a moderate increase in the extracellular concentration of glutamate an hour after the washout. Another possibility is that protective mechanisms, such as the synthesis of stress proteins, have sufficient time to be activated.
The molecular identity of the subtype or subtypes of NMDA receptor expressed by NT2-N cells responsible for the excitotoxic response has not been established. Younkin et al. (1993) used RT-PCR to detect the presence of mRNA for the NR1 subunit of the NMDA receptor. The NR1 subunit is the locus of glycine sensitivity and both homomeric NR1/NR 1 receptors and heteromeric NR1/NR2 receptors have been shown to exhibit this property. However, patch cell recordings in NT2-N cells favor the expression of heteromeric NMDA receptors (Younkin et al., 1993). Polyamine sensitivity appears to be jointly controlled by both NR1 and NR2 subunits (Durand et al., 1992; Williams et 

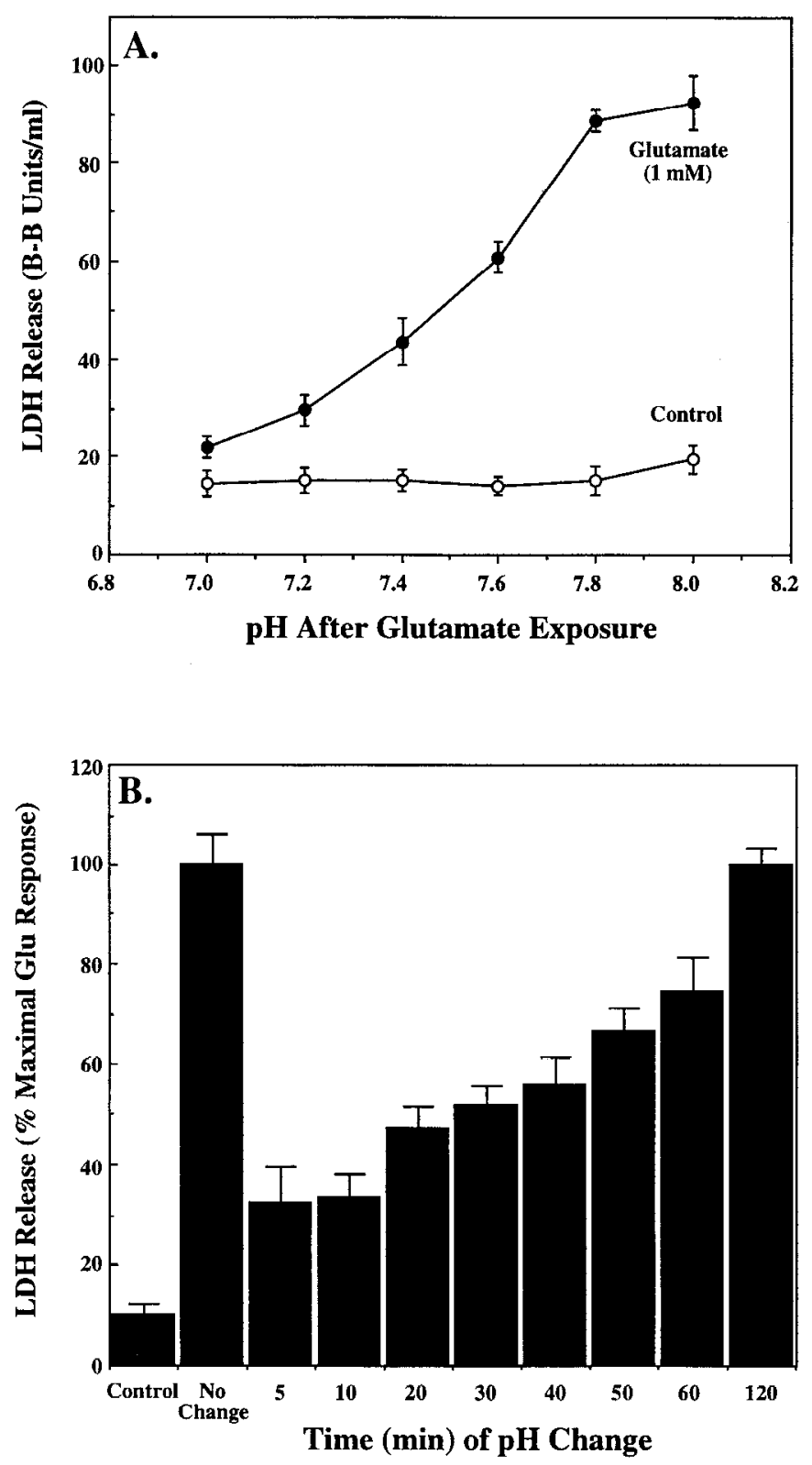

Figure 14. A decrease in $\mathrm{pH}$ after the glutamate washout rescues the cells from glutamate toxicity. $A$, Cells were treated with $1 \mathrm{~mm}$ glutamate

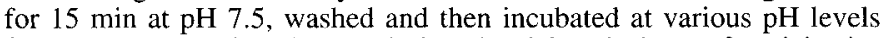
for $24 \mathrm{hr}$. Decreasing the $\mathrm{pH}$ during the delayed phase of toxicity inhibited the toxic effect of glutamate, with near complete protection observed at $\mathrm{pH}$ 7.0. In contrast, alkaline $\mathrm{pH}$ accentuated glutamate toxicity. Each point is the mean \pm SEM of eight determinations representative of three experiments. $B$, Cells were treated with $1 \mathrm{~mm}$ glutamate for $15 \mathrm{~min}$ at $\mathrm{pH} 8.0$ and washed. Reducing the $\mathrm{pH}$ to 7.0 at various times after termination of glutamate treatment inhibited the toxic response. No protection was observed if the $\mathrm{pH}$ was decreased more than $1 \mathrm{hr}$ after glutamate exposure was terminated. Each bar is the mean \pm SEM of eight determinations representative of three experiments.

al., 1994). Several splice variants of NR1 have been identified and a subset of these variants that lack the amino-terminal $\left(5^{\prime}\right)$ insert such as the NR1A variant, are required for spermine sensitivity (Williams et al., 1994). Moreover, this glycine-independent stimulation by spermine occurs in heteromeric NR1A/ NR2B receptors, but not in NR1A/NR2A or NR1A/NR2C receptors (Williams et al., 1994). Heteromeric NR1/NR2B receptors have been shown to have a high affinity for the atypical

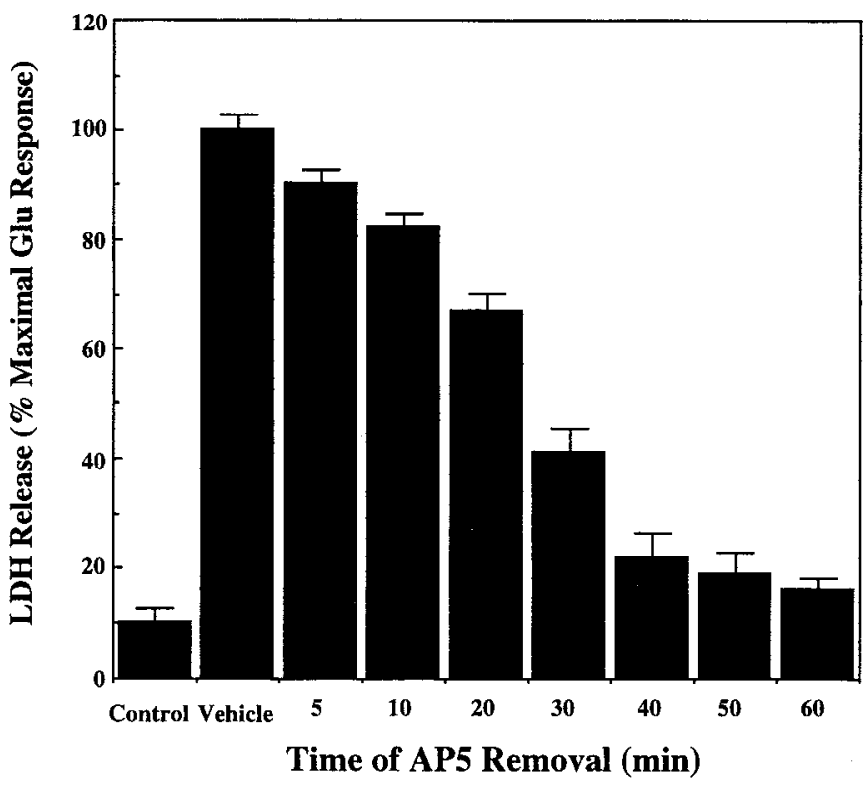

Figure 15. Rescue of NT2-N neurons by AP5 is duration dependent. Cells were exposed to $1 \mathrm{~mm}$ glutamate for $15 \mathrm{~min}$ and washed. AP5 was added immediately after the glutamate washout and removed at various intervals. The degree of rescue was directly related to the duration of antagonist treatment with complete rescue observed after $1 \mathrm{hr}$. Each bar is the mean \pm SEM of eight determinations representative of three experiments.

antagonist ifenprodil $\left(I C_{50} 0.34 \mu \mathrm{M}\right)$ whereas NR1/NR2A receptors have a much lower affinity $\left(I C_{S 0}, 146 \mu \mathrm{M}\right)$ (Williams, 1993; Williams et al., 1993). In hippocampal neurons, two-component inhibition of NMDA receptor currents by ifenprodil with $I C_{50}$ values of 0.75 and $16 \mathrm{I} \mu \mathrm{M}$ has been reported (Legendre and Westbrook, 1991). The $I C_{50}$ of ifenprodil for the inhibition of toxicity in the NT2-N cells is $0.6 \mu \mathrm{M}$, consistent with the presence of heteromeric NR 1 A/NR2B receptors that are responsible for the toxic response to glutamate in these cells. This is also consistent with the observation that the NR1/NR2B subtype predominates in neonatal rat brain and the youngest primary cultured neurons (Williams et al., 1993; Zhong et al., 1994). These results do not exclude low level of expression or involvement in toxicity of other combinations of NMDA receptor subunits in NT2-N cells.

Considerable attention has recently been focused on the role of nitric oxide in excitotoxic cell death. It has been speculated that NO can be converted into toxic free radicals and can also serve as an intercellular messenger to stimulate further release of glutamate during the amplification stage (Dawson et al., 1993). Inhibitors of nitric oxide synthase have been shown to prevent the excitotoxic response in primary cultured cortical neurons (Dawson et al., 1991, 1993). Moreover, the onset of susceptibility to excitotoxic injury corresponds to the expression of nitric oxide synthase in this preparation (Dawson et al., 1993). However, NOS inhibitors did not attenuate the excitotoxic response in NT2-N cells indicating that NO is not involved in the cxitotoxic response in these cells. This should not be completely unexpected since neurons expressing NOS only represent $1 \%$ of neurons in the rat and human cortex (Bredt et al., 1991). This is further supported by the observation that glutamate did not increase cGMP levels indicating that glutamate does not significantly elevate NO levels in these cells. The presence of functional guanylate cyclase in NT2-N cells was confirmed by the 

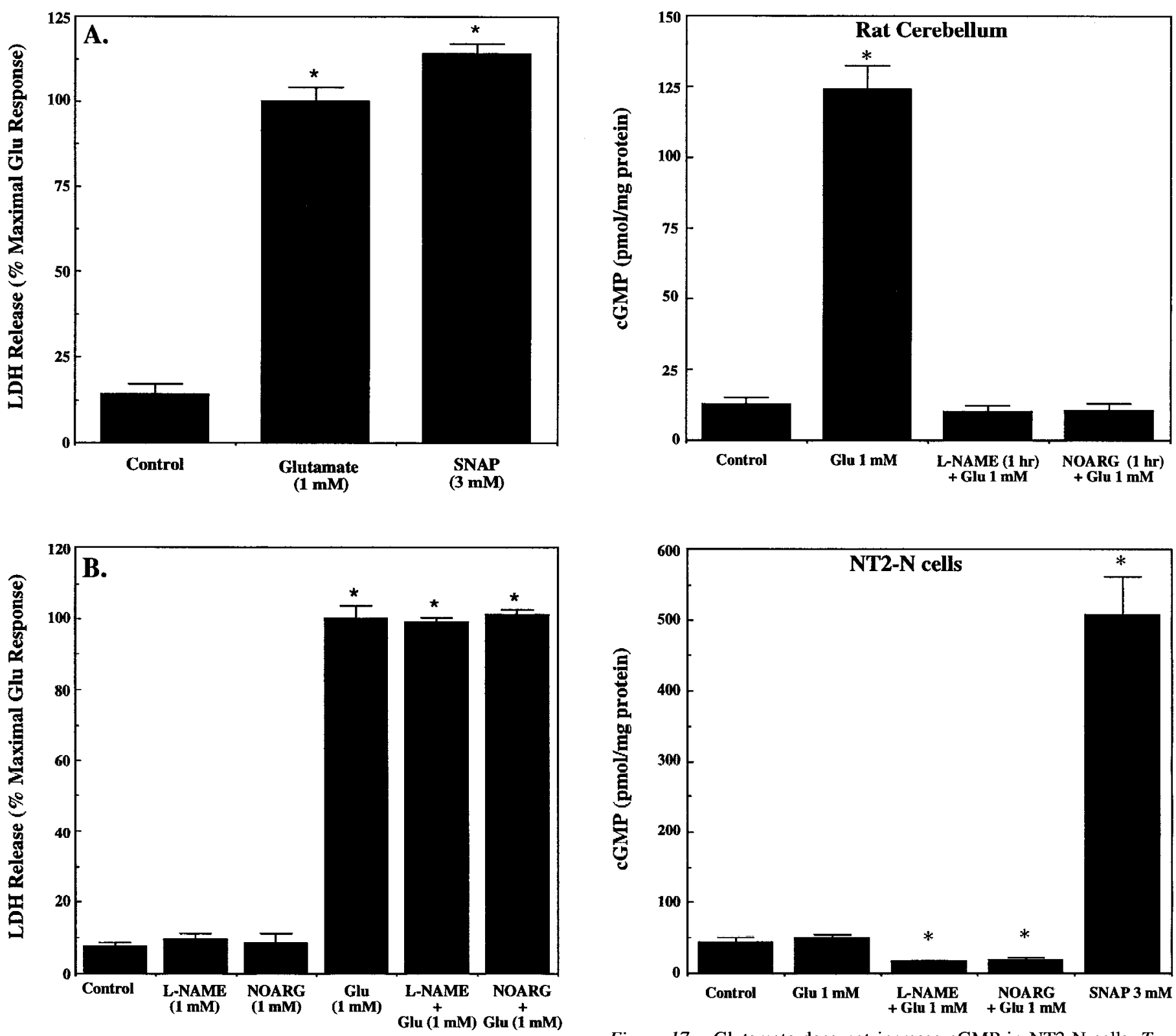

Figure 16. Nitric oxide kills NT2-N cells but inhibition of nitric oxide synthase does not prevent glutamate toxicity. $A$, Cells were exposed to glutamate for $15 \mathrm{~min}$ or the nitric oxide releasing compound S-nitroso$\mathrm{N}$-acetylpencillamine (SNAP) for $24 \mathrm{hr}$. SNAP produced even more toxicity than a maximally effective concentration of glutamate. $B$, Cells were treated with NOS inhibitors alone, glutamate alone or a combination of glutamate plus NOS inhibitor. For the combined treatment, cells were preincubated with NOS inhibitors for $1 \mathrm{hr}$, treated with $1 \mathrm{~mm}$ glutamate for $15 \mathrm{~min}$ in the presence of NOS inhibitors and maintained in NOS inhibitors for the next $24 \mathrm{hr}$. Neither NOS inhibitor produced any reduction in toxicity suggesting that nitric oxide does not mediate glutamate toxicity in these cells. Each bar is the mean \pm SEM of eight determinations representative of three experiments. ${ }^{*}$ indicates significant difference from control at $p<0.05$.

ability of the NO-releasing agent SNAP to produce an 11-fold increase in cGMP levels. Surprisingly, the NOS inhibitors significantly reduced the basal level of cGMP in NT2-N cells suggesting the presence of NOS that is activated under basal conditions. This would appear to contradict the finding that no NADPH diaphiorase activity was detected in NT2-N cells. However, this could be explained either by the presence of a low

Figure 17. Glutamate does not increase cGMP in NT2-N cells. Top, Rat cerebellar slices were incubated with or without NOS inhibitors for $1 \mathrm{hr}$ and then exposed to glutamate for $2 \mathrm{~min}$. Glutamate caused a $10-$ fold increase in cGMP levels and NOS inhibitors completely blocked the glutamate effect. Bottom, NT2-N cells were incubated with or with out NOS inhibitors for $1 \mathrm{hr}$ and then exposed to $1 \mathrm{mM}$ glutamate for 2 min. Glutamate did not cause any increase in the basal cGMP levels. A 5 min exposure to NO releasing compound S-nitroso- $\mathrm{N}$-acetylpencillamine (SNAP) resulted in an 11-fold increase in the cGMP levels in NT2-N cells. Asterisk indicates a significant difference from untreated controls at $p<0.05$. Each bar is the mean \pm SEM of three determinations representative of three experiments.

level of NOS in cach NT2-N cell that is below the level of detection or by the presence of other types of NOS not yet characterized. Since these cells exhibit a prototypical excitotoxic response, it is clear that NOS is not required for such a response in these neurons. This is in agreement with reports from other laboratories in which primary cultured cortical neurons are not protected by NOS inhibitors (Choi, 1992).

In summary, the NT2-N cell line represents a unique and attractive model system in which to study the molecular basis for 

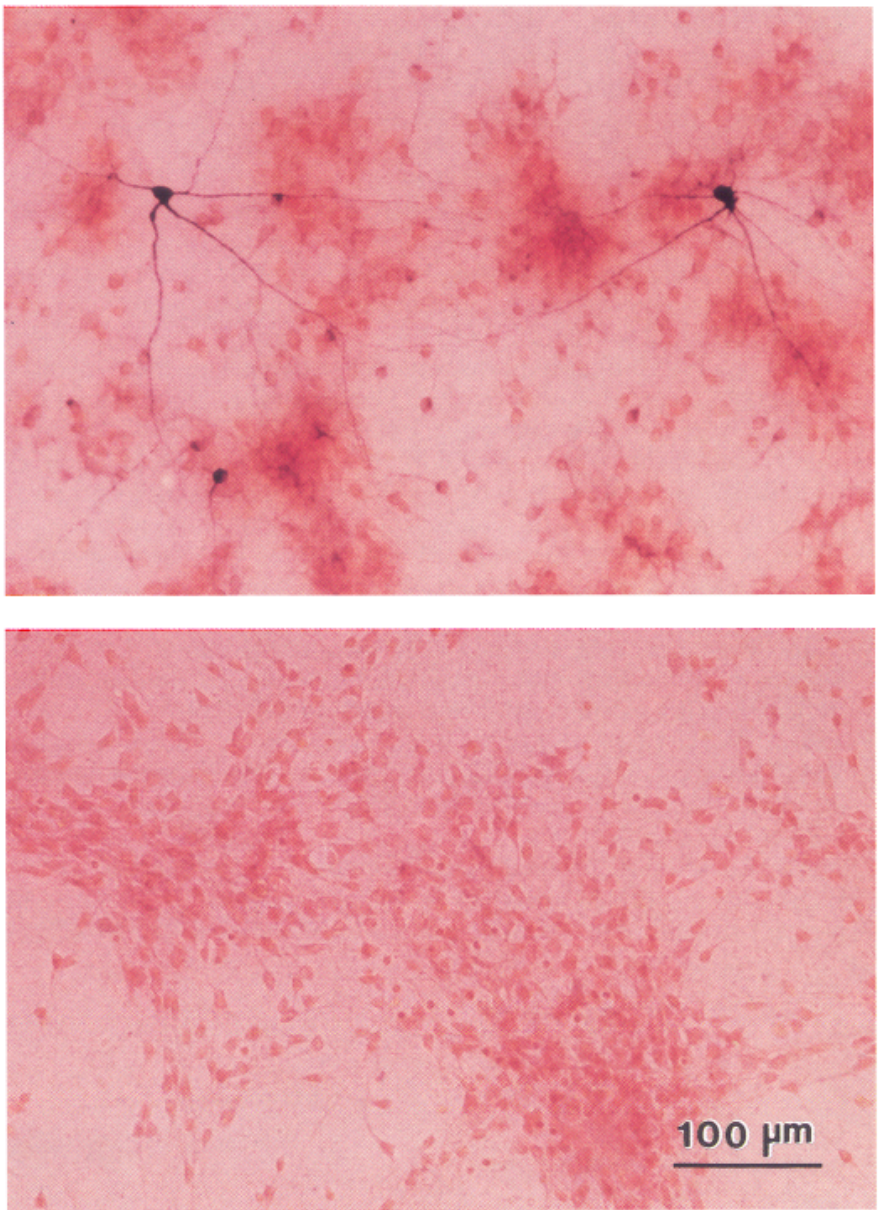

Figure 18. Nitric oxide synthase (NOS) positive cells are not detected in NT2-N cultures. The presence of NADPH-diaphorase activity, a sensitive marker for the presence of NOS was measured in primary cultured cortical neurons and NT2-N cultures. Top, Discrete neurons in the rat primary culture exhibited robust NADPH-diaphorase activity. Bottom, No NADPH activity was detected in NT2-N cells. These pictures are representative of results obtained with three different sets of cultures in five separate experiments.

excitotoxic cell death. They express multiple subtypes of glutamate receptor, exhibit a robust and prototypical excitotoxic response to glutamate and they survive in culture for several months. Based on the effects of modulators of the NMDA receptor, it appears that the excitotoxic stimulus is mediated by the NR1/NR2B subtype. We have used these cells to characterize the amplification stage of excitotoxic injury and have discovered that an acute (1 hr) blockade of NMDA receptors is necessary and sufficient to block amplification and prevent cell death. Finally, the results with NOS inhibitors and NADPH diapharose staining indicate that nitric oxide is not required for excitotoxic injury of human neuronal cells.

\section{References}

Andrews PW (1984) Retinoic acid induces neuronal differentiation of a cloned human embryonal carcinoma cell line in vitro. Dev Biol 103:285-293.

Bredt DS, Snyder SH (1989) Nitric oxide mediates glutamate-linked enhancement of c-GMP levels in cerebellum. Proc Natl Acad Sci USA 86:9030-9033.

Bredt DS, Glatt CE, Hwang PM, Fotuhi M, Dawson TM, Snyder SH (1991) Nitric oxide synthase protein and mRNA are discretely lo- calized in neuronal populations of the mammalian CNS together with NADPH diaphorase. Neuron 7:615-624.

Cabaud PG, Wroblewski F (1958) Colorimetric measurement of lactic dehydrogenase activity of body fluids. Am J Clin Pathol 30:234-239.

Choi DW (1992) Excitotoxic Cell Death. J Neurobiol 23:1261-1276.

Choi DW (1985) Glutamate neurotoxicity in cortical cell culture is calcium dependent. Neurosci Lett 58:293-297.

Choi DW (1988) Glutamate neurotoxicity and diseases of the nervous system. Neuron 1:623-634.

Choi DW, Koh JY, Peters S (1988) Pharmacology of glutamate neurotoxicity in cortical cell culture: attenuation by NMDA antagonists. J Neurosci 8:185-196.

Chovanes GI, Cologer A, Lu S, Tjan C, Simon N (1992) Excitatory amino acid-induced cytotoxicity in continuous neural cell lines. J Neurotrauma 9:383.

Dawson VL, Dawson TM, London E D, Bredt DS, Snyder SH (1991) Nitric oxide mediates glutamate neurotoxicity in primary cortical culture. Proc Natl Acad Sci USA 88:6368-6371.

Dawson VL, Dawson TM, Bartley DA, George RU, Solomon SH (1993) Mechanisms of nitric oxide-mediated neurotoxicity in primary brain. J Neurosci 13:2651-2661.

Durand GM, Gregor P, Zheng X, Bennett MVL, Uhl GR, Zukin RS (1992) Cloning of an apparent splice variant of the rat $N$-methyl-Daspartate receptor NMDAR1 with altered sensitivity to polyamines and activators of protein kinase C. Proc Natl Acad Sci USA 89:93599363.

East SJ, Garthwaite J (1991) NMDA receptor activation in rat hippocampus induces cyclic GMP formation through the L-arginine-nitric oxide pathway. Neurosci Lett 123:17-19.

Garthwaite J, Garthwaite G (1987) Cellular origins of cyclic GMP responses to excitatory amino acid receptor agonists in rat cerebellum in vitro. J Neurochem 48:29-39.

Garthwaite G, Garthwaite J (1988) Cyclic GMP and cell death in rat cerebellar slices. Neuroscience 26:321-326.

Hansen M, Nielsen S, Berg K (1989) Re-examination and further development of a precise and rapid dye method for measuring cell growth/kill. J Immunol Methods 119:203-210.

Hardy M, Younkin D, Tang CM, Pleasure J, Shi QY, Williams M, Pleasure D (1994) Expression of non-NMDA glutamate receptor channel genes by clonal human neurons. J Neurochem 63:482-489.

Hartley DM, Choi DW (1989) Delayed rescue of $N$-methyl-D-aspartate receptor-mediated neuronal injury in cortical culture. J Pharmacol Exp Ther 250:752-758.

Ivins JK, Raper JA, Pittman RN (1991) Intracellular calcium levels do not change during contact mediated collapse of chick DRG growth cone structure. J Neurosci 11:1597-1608.

Kimelberg H, Goderie S, Higman S, Pang S, Waniewski R (1990) Swelling-induced release of glutamate, aspartate, and taurine from astrocyte cultures. J Neurosci 10:1583-1591.

Kleinman HK, McGarvey ML, Hassell JR, Star VL, Cannon FB, Laurie GW, Martin GR (1986) Basement membrane complexes with biological activity. Biochemistry 25:312-318.

Koh J, Goldberg MP, Hartley DM, Choi DW (1990) Non-NMDA receptor-mediated neurotoxicity in cortical culture. J Neurosci 10:693705

Lee VM-Y, Andrews PW (1986) Differentiation of NTERA-2 clonal human embryonal carcinoma cells into neurons involves the induction of all three neurofilament proteins. J Neurosci 6:514-521.

Legendre P, Westbrook GL (1991) Ifenprodil blocks $N$-methyl-D-aspartate receptors by a two-component mechanism. Mol Pharmacol 40:289-298

Levy DI, Lipton SA (1990) Comparison of delayed administration of competitive and uncompetitive antagonists in preventing NMDA receptor-mediated neuronal death. Neurology 40:852-855.

Manev H, Favaron M, Guidotti A, Costa E (1989) Delayed increase of $\mathrm{Ca}^{2+}$ influx elicited by glutamate: role in neuronal death. Mol Pharmacol 36:106-112.

Meldrum B (1985) Possible therapeutic applications of antagonists of excitatory amino acid neurotransmitters. Clin Sci 68:113-122.

Mosmann T (1983) Rapid colorimetric assay for cellular growtyh and survival: application to proliferation and cytotoxicity assays. J Immunol Methods 65:55-63.

Murphy TH, Miyamoto M, Sastre A, Schnaar RL, Coyle JT (1989) Glutamate toxicity in a neuronal cell line involves inhibition of cystine transport leading to oxidative stress. Neuron 2:1547-1558. 
Pittman RN, Wang S, DiBenedetto AJ, Mills JC (1993) A system for characterizing cellular and molecular events in programmed neuronal cell death. J Neurosci 13:3669-3680.

Pleasure SJ, Constance P, Lee VM-Y (1992) Purc, postmitotic, polarized human neurons derived for NTera 2 cells provide a system for expressing exogenous proteins in terminally differentiated neurons. $\mathbf{J}$ Neurosci 12:1802-1815.

Ray WJ, Gottlieb DJ (1993) Expression of ionotropic glutamate receptor genes by P19 embryonal carcinoma cells. Biochem Biophys Res Commun 197:1475-1482.

Ronnett GV, Hester LD, Nye JS, Connors K, Snyder SH (1990) Human cortical neuronal cell line: establishment from a patient with unilateral megalencephaly. Science 248:603-605.

Ronnett GV, Hester LD, Nye JS, Snyder SH (1994) Human cerebral cortical cell lines from a patient with unilateral megalencephaly and Rasmussen's encephalitis. Neuroscience 63:1081-1099.

Rosenberg P, Amin S, Leitner M (1992) Glutamate uptake disguises neurotoxic potency of glutamate agonists in cerebral cortex in dissociated cell culture. J Neurosci 12:56-61.

Rothman S (1984) Synaptic release of excitatory amino acid neurotransmitter mediates anoxic neuronal death. J Neurosci 4:1884-1891.

Rothman SM, Olney JW (1987) Excitotoxicity and the NMDA receptor. Trends Neurosci 10:299-302.

Rothman SM, Ihurston JH, Hauhart RE (1987) Delayed neurotoxicity of excitatory amino acids in vitro. Neuroscience $22: 471-480$.

Shalaby IA, Chenard BL, Prochniak MA, Butler TW (1992) Neuroprotective effects of the $N$-methyl-D-aspartate receptor antagonists ifenprodil and SL-82,0715 on hippocampal cells in culture. J Pharmacol Exp Ther 260:925-932.

Szatkowski M, Attwell D (1994) Triggering and execution of neuronal death in brain ischemia: two phases of glutamate release by different mechanisms. Trends Neurosci 17:359-365.

Szatkowski M, Barbour B, Attwell D (1990) Non-vesicular release of glutamate from glial cells by reversed electrogenic glutamate uptake. Nature 348:443-446

Tang CM, Dichter M, Morad M (1990) Modulation of the $N$-methylD-aspartate channel by extracellular $\mathrm{H}^{+}$. Proc Natl Acad Sci USA 87 : 6445-6449.

Turetsky DM, Huettner JE, Gottlieg DI, Goldberg MP, Choi DW (1993) Glutamate receptor-mediated currents and toxicity in embryonal carcinoma cells. J Neurobiol 24:1157-1169.

Williams K (1993) Ifenprodil discriminates subtypes of the $N$-methylD-aspartate receptor: selectivity and mechanisms at recombinant heteromeric receptors. Mol Pharmacol 44:851-859.

Williams K, Dichter MA, Molinoff PB (1992) Up-regulation of $N$-methyl-D-aspartate receptors on cultured cortical neurons after exposure to antagonists. Mol Pharmacol 42:147-151.

Williams K, Russell SL, Shen YM, Molinoff PB (1993) Developmental switch in the expression of NMDA receptors occurs in vivo and in vitro. Neuron 10:267-278.

Williams K, Zappia AM, Pritchett DB, Shen YM, Molinoff PB (1994) Sensitivity of the $N$-methyl-D-aspartate receptor to polyamines is controlled by NR2 subunits. Mol Pharmacol 45:803-809.

Younkin DP, Tang CM, Hardy M, Reddy VR, Shi QY, Pleasure SJ, Lee VM, Pleasure D (1993) Inducible epression of neuronal glutamate receptor channels in the NT2 human cell line. Proc Natl Acad Sci USA 90:2174-2178.

Zhong J, Russell S L, Pritchett DB, Molinoff PB, Williams K (1994) Expression of mRNAs encoding subunits of the $N$-methyl-D-aspartate receptor in cultured cortical neurons. Mol Pharmacol 45:846-853. 